\title{
CHOICE OF LAW IN INTERSTATE TORTS
}

\section{FRIEDRICH JUENGER $\dagger$}

Six years ago the New York Court of Appeals decided to discard the conflict of laws rule which previously applied invariably the substantive law of the place of injury in multistate tort situations. In Babcock v. Jackson ${ }^{1}$ the court held that a New York auto passenger could recover from the New York driver under New York law, although both the negligent act and the injury occurred in Ontario, and the Ontario guest statute would have barred recovery. Since Babcock, no fewer than sixteen states have abandoned the lex loci delicti rule and endorsed novel solutions of tort choice of law problems. ${ }^{2}$ Several diversity courts ${ }^{3}$ and the District of Columbia have followed suit. ${ }^{4}$ It seems clear that lex loci is no longer the federal choice of law rule. ${ }^{5}$ This is a remarkable development considering that the rule was once followed in word, if not in deed, by virtually every court in the United States. ${ }^{6}$

$\dagger$ Professor of Law, Wayne State University. LL.B. 1960, Columbia University; M.C.L. 1958, University of Michigan.

The author would like to acknowledge the assistance of Gary L. Smith, J.D. 1969, Wayne State University, in the preparation of this Article.

112 N.Y.2d 473, 191 N.E.2d 279, 240 N.Y.S.2d 743 (1963).

2 Armstrong v. Armstrong, 441 P.2d 699 (Alas. 1968); Schwartz v. Schwartz, 103 Ariz. 562, 447 P.2d 254 (1968) ; Reich v. Purcell, 67 Cal. 2d 551, 432 P.2d 727, 63 Cal. Rptr. 31 (1967); Wartell v. Formusa, 34 Ill. 2d 57, 213 N.E.2d 544 (1966); Fabricius v. Horgen, 257 Iowa 268, 132 N.W.2d 410 (1965); Wessling v. Paris, 417 S.W.2d 259 (Ky. 1967) ; Schneider v. Nichols, 280 Minn. 139, 158 N.W.2d 254 (1968) ; Mitchell v. Craft, 211 So.2d 509 (Miss. 1968) ; Kennedy v. Dixon, 439 S.W.2d 173 (Mo. 1969); Clark v. Clark, 107 N.H. 351, 222 A.2d 205 (1966) ; Mellk v. Sarahson, 49 N.J. 226, 229 A.2d 625 (1967); Casey v. Manson Constr. \& Eng'r Co., 247 Ore. 274, 428 P.2d 898 (1967) ; Griffith v. United Air Lines, Inc., $416 \mathrm{~Pa}$. 1, 203 A.2d 796 (1964); Woodward v. Stewart, 243 A.2d 917 (R.I. 1968), petition for cert. dismissed, 393 U.S. 957 (1969); Conklin v. Horner, 38 Wis. 2d 468, 157 N.W.2d 579 (1968).

3 Watts v. Pioneer Corn Co., 342 F.2d 617 (7th Cir. 1965) ; Lowe's North Wilkesboro Hardware, Inc. v. Fidelity Life Ins. Co. 319 F.2d 469 (4th Cir. 1963); Zucker v. Vogt, 200 F. Supp. 340 (D. Conn. 1961), aff'd, 329 F.2d 426 (2d Cir. 1964); cf. Merchants Nat'l Bank \& Trust Co. v. United States, 272 F. Supp. 409 (D.N.D. 1967) (applying presumed modern state conflicts rule via the choice of law provisions of the Federal Torts Claims Act). Contra Brendle v. General Tire \& Rubber Co., 408 F.2d 116 (4th Cir. 1969); Gormson v. Capital Airlines, 345 F.2d 750 (6th Cir. 1965); Bannowski v. Krauser, 294 F. Supp. 1204 (D. Colo. 1969).

4 See Williams v. Rawlings Truck Line, Inc., 357 F.2d 581 (D.C. Cir. 1965).

5 See Romero v. International Terminal Operating Co., 358 U.S. 354 (1959) ; Lauritzen v. Larsen, 345 U.S. 571 (1953) ; Scott v. Eastern Air Lines, Inc., 399 F.2d 14 (3d Cir.) (opinion upon rehearing), cert. denied, 393 U.S. 979 (1968); McClure v. United States Lines Co., 368 F.2d 197 (4th Cir. 1966) ; cf. Richards v. United States, 369 U.S. 1 (1962).

6 See generally G. Stumberg, Princtples of Conflict of Laws 181-83 (3d ed. 1963 ) ; 11 AM. JUR. Conflict of Laws $\$ 182$ (1937); 16 AM. JUR. 2d Conflict of Laws $\S 71$ (1964). 
Courts that still feel bound to look exclusively to the state of injury for the substantive rules governing multistate torts do so half-heartedly, out of respect for certainty and stare decisis, rather than from conviction of the soundness of the old rule. ${ }^{7}$ The others have embraced modern conflicts thinking cheerfully, and the terms, "significant relationship," 8 "governmental interest," " "policy," 10 "concern," 11 and "false conflict" 12 have become part and parcel of the judicial vocabulary.

This conflicts revolution ${ }^{13}$ was motivated by the pronunciamentos of legal scholars. It was inspired principally by the attacks of Cook, ${ }^{14}$ Lorenzen, ${ }^{15}$ and Yntema ${ }^{16}$ on the vested rights theory and the First Restatement by Cavers's influential early article, ${ }^{17}$ by Ehrenzweig's calls for law and reason, ${ }^{18}$ and by Currie's essays on governmental interest analysis. ${ }^{19}$ Understandably, judicial adoption of new techniques for the solution of choice of law problems has been applauded by academicians. ${ }^{20}$ Nonetheless, even among those who warmly welcomed

7 McGinty v. Ballentine Produce, Inc., 241 Ark. 533, 408 S.W.2d 891 (1966); Landers v. Landers, 153 Conn. 303, 216 A.2d 183 (1966) ; Friday v. Smoot, - Del. 211 A.2d 594 (1965); Hopkins v. Lockheed Aircraft Corp., 201 So. 2d 749, rev'g on rehearing, 201 So.2d 743 (Fla. 1967); Abendschein v. Farrell, - Mich. - 170 N.W.2d 137 (1969) ; Browning v. Shackelford, 196 So. 2d 365 (Miss. 1967); Petrea v. Ryder Tank Lines, Inc., 264 N.C. 230, 141 S.E.2d 278 (1965); Cherokee Laboratories, Inc. v. Rogers, 398 P.2d 520 (Okla. 1965); Marmon v. Mustang Aviation, Inc., 416 S.W.2d 58 (Tex. Civ. App. 1967), aff'd, 430 S.W.2d 182 (1968); see McDaniel v. Sinn, 194 Kan. 625, 400 P.2d 1018 (1965); Oshiek v. Oshiek, 244 S.C. 249, 136 S.E.2d 303 (1964). But see White v. King, 244 Md. 348, 223 A.2d 763 (1966).

8 E.g. Schwartz v. Schwartz, 103 Ariz. 562, 447 P.2d 254 (1968); Griffith v. United Air Lines, Inc., $416 \mathrm{~Pa} .1,203$ A.2d 796 (1964).

${ }^{9}$ E.g., Reich v. Purcell, 67 Cal. 2d 551, 432 P.2d 727, 63 Cal. Rptr. 31 (1967); Wartell v. Formusa, 34 Ill. 2d 57, 213 N.E.2d 544 (1966).

10 E.g., Swanson v. Badger Mut. Ins. Co., 275 F. Supp. 544 (N.D. Ill. 1967) ; Mellk v. Sarahson, 49 N.J. 226, 229 A.2d 625 (1967).

11 E.g., Kopp v. Rechtzigel, 273 Minn. 441, 141 N.W.2d 526 (1966) ; Babcock v. Jackson, 12 N.Y.2d 473, 191 N.E.2d 279, 240 N.Y.S.2d 743 (1963).

12 E.g., Williams v. Rawlings Truck Line, Inc., 357 F.2d 581 (D.C. Cir. 1965);

Zucker v. Vogt, 329 F.2d 426 (2d Cir. 1964).

13 The phrase is borrowed from Ehrenzweig, A Connter-Revolution in Conflicts

Law? From Beale to Cavers, 80 HaRv. L. REv. 377 (1966).

14 W. Cook, The Logical and Legar Bases of the Conflict of Laws (1942). 15 Lorenzen \& Heilman, The Restatement of the Conflict of Lazus, 83 U. PA. L.

REv. 555 (1935); Iorenzen, Territoriality, Public Policy and the Conflict of Laws,

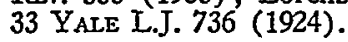

16 Yntema, The Hornbook Method and the Conflict of Laws, 37 YALE L.J. 468 (1928).

17 Cavers, $A$ Critique of the Choice-of-Lawe Problem, 47 HARv. I. REv. 173 (1933).

18 For this phase of Ehrenzweig's writing see Ehrenzweig, The Lex Fori-Basic Rule in the Conflict of Laws, 58 MICH. L. REv. 637 \& Note (1960).

19 B. Currie, Selected Essays on the Conflict of Laws (1963) [hereinafter cited as CurrIE]; Currie, The Disinterested Third State, 28 LAw \& Contenr. Prob. 754 (1963).

${ }^{20}$ See Comments on Babcock v. Jackson, A Recent Development in Conflict of Laws, 63 Colum. L. REv. 1212 (1963) (by Cavers, Cheatham, Currie, Ehrenzweig, Leflar, and Reese). 
this development there is no agreement either on the methods to be followed by the courts or the results to be derived in a particular case from a given method. Authors, usually found peacefully united in a string citation, are often at loggerheads in a lively debate that has contributed to a literature of impressive magnitude and quality. To an increasing extent this literature is marked by critical comment rather than adulation for the handiwork of the courts. ${ }^{21}$ Cavers made an eloquent case for new principles, ${ }^{22}$ which may have earned him the title of counterrevolutionary. ${ }^{23}$ Other authors entirely reject current approaches, primarily because of practical considerations. ${ }^{24}$ They complain that the unfreezing of conflicts law has led to vacillation on the part of the courts, to uncertainty on the part of judges, lawyers, and clients, and to a body of law which is unmanageable and obscure. Indeed, the richly annotated opinions, frequent appeals, separate concurrences and vociferous dissents in the home state of $B a b c o c k{ }^{25}$ indicate that this decision has created more problems than it has resolved. Such uncertainty may be too high a price to pay for the abolition of a rule, however "wooden," "mechanical," or "ossified" it may have been.

The unsatisfactory state of the law is not simply a product of the uncertainty that accompanies new learning; nor does the fault lie entirely with the eclecticism of the courts or with their failure to use properly and consistently the methodologies proffered by theoreticians. Although judges are wont to base decisions on alternative choice of law theories and to use terminology indiscriminately, ${ }^{26}$ the problem inheres in the nature of the modern approaches rather than their practical application.

21 Suggestive title headings reveal a certain disenchantment with the present state of conflicts law. See, e.g., Note, Conflict in the Conflict of Lazes: $A$ Need for Uniformity, 61 Nw. L. Rev. 329 (1966); Comment, Conflict of Laws: Guest Statutes Four Years After the Millenninm, 20 ALA. L. REv. 90 (1967).

22 D. Cavers, The Chotce of Law Process (1965) [hereinafter cited as Cavers].

23 Compare Ehrenzweig, supra note 13, with Baade, Counter-Revolution or Alliance for Progress? Reflections on Reading Cavers, The Choice-of-Law Process, 46 TEX. L. REv. 141 (1967).

24 Foley, Fragnentation in the Conflict of Lazes, 47 OREGoN L. REv. 377 (1968); LaBrum, The Frnits of Babcock and Seider: Injustice, Uncertainty and Forum Shopping, 54 A.B.A.J. 747 (1968); Rosenberg, An Opinion for the New York Court of Appeals, in Two Viezs on Kell v. Henderson, 67 ColuM. L. Rev. 459 (1967); Rosenberg, in Comments on Reich v. Purcell, 15 U.C.L.A.L. Rev. 551, 641 (1968); Sparks, Babcock v. Jackson-A Practicing Attorney's Reflections Upon the Opinion and Its Implications, 31 INS. CouNSEL J. 428 (1964).

25 See, e.g., Miller v. Miller, 22 N.Y.2d 12, 237 N.E.2d 877, 290 N.Y.S.2d 734 (1968) ; Macey v. Rozbicki, 18 N.Y.2d 289, 221 N.E.2d 380, 274 N.Y.S.2d 591 (1966); Dym v. Gordon, 16 N.Y.2d 120, 209 N.E.2d 792, 262 N.X.S.2d 463 (1965). For a recent list of New York cases citing Babcock, see Baer, Two Approaches to Guest Statutes in the Confict of Lazes: Mechanical Jurisprudence Versus Groping for Contacts, 16 Buffalo L. Rev. 537, 554-55 n.105 (1967).

20 This tendency has been noted by $R$. Crampton \& D. Currie, Conflict of LAws 257 (1968). It is discussed and exemplified by Leflar, Conflict of Lazes, 1968 ANNUAI SURVEY of AM. LAW 31, 45-46 (1969). 
While these theories purport to apply across the board to all choice of law situations, they have created difficulties primarily in the law of torts. $^{27}$ It therefore seems appropriate to inquire into the assumptions underlying modern methods of analysis, the workability of such methods, and the alternatives available, with specific regard to choice of law in tort cases. However, some general comment on the nature of the approaches courts have adopted is required since the main characteristic of pertinent case law is its strong reliance on theory. ${ }^{28}$

\section{Current Methodologies}

\section{A. Governmental (Forum) Interests}

The term "interest," in the context of determining the reach of forum law, was originally used by the Supreme Court in workmen's compensation cases ${ }^{29}$ in which the Court rejected the argument that it was unconstitutional to apply forum law to transactions involving certain contacts with other states. These arguments were derived from earlier holdings which suggested that the Constitution might compel a given choice of law,,$^{30}$ or at least limit substantially the application of the lex fori. ${ }^{31}$ In allowing the states to claim a fairly broad territorial reach for their workmen's compensation acts, the Court decided, in the words of Paul Freund, "what a state court might legitimately do, not what it should preferably do as a matter of choice of law within a permissible latitude under the Constitution." 32 But Freund also believed that the Court's opinions "are suggestive of an approach in conflicts cases generally." 33 Brainerd Currie postulated a "governmental" interest of every state in the effectuation of the policies underlying its laws, an interest to which he attributed extraordinary strength and vitality. ${ }^{34}$

27 See A. Ehrenzwetg, Private International Law 70, 72-73 (1962).

28 Some of the cases have inspired symposia. E.g., Rosenberg \& Trautman, Two Viezes on Kell v. Henderson, 67 ColUM. L. REv. 459 (1967) ; 'Comments on Babcock v. Jackson, $A$ Recent Development in Conflict of Laws, 63 ColuM. L. REv. 1212 (1963); Comments on Reich v. Purcell, 15 U.C.L.A.L. Rev. 551 (1968).

29 Carroll v. Lanza, 349 U.S. 408 (1955) ; Pacific Employers Ins. Co. v. Industrial Accident Comm'n, 306 U.S. 493 (1939); Alaska Packers Ass'n v. Industrial Accident Comm'n, 294 U.S. 532 (1935); see CuRrIe 201-05, 613-14.

30 Bradford Electric Light Co. v. Clapper, 286 U.S. 145 (1932); New York Life Ins. Co. v. Dodge, 246 U.S. 357 (1918).

31 Flartford Accident \& Indemnity Co. v. Delta \& Pine Land Co., 292 U.S. 143 (1934) ; Home Ins. Co. v. Dick, 281 U.S. 397 (1930).

32 Freund, Chief Justice Stone and the Conflict of Laws, 59 Harv. L. Rev. 1210, 1220 (1946); see CURRIE 613-14.

33 Freund, supra note 32 , at 1220 .

34 See generally CuRRIE, which is a collection of several of the author's law review articies. A summary of the method appears in chapter 4 at 183-84, which originally appeared as Currie, Notes on Methods and Objectives in the Conflict of Laws, 1959 DURE L.J. 171, 178. Currie subsequently modified his views somewhat. See articles cited in notes 19-20 supra. A later summary of the method prepared by Currie appears in E. Cheatham, E. Griswold, W. Reese \& M. Rosenberg, Conflict OF LAws $477-78$ (5th ed. 1964). 
Under his theory courts are duty-bound not to sacrifice the forum state's interest. ${ }^{35}$ Their function in the area of choice of law should be limited to ascertaining the relevant policies of the competing laws and, if the forum is legitimately interested, to apply the lex fori so as to effectuate its policies. Currie warned that relinquishing forum interests unilaterally in favor of interstate justice would be "quixotic." 36 A mutual give and take through diplomatic and political techniques might be proper for the legislature, but he characterized the prospect of "trading off ... the rights of one group of citizens for those of another . . . [as] not . . . wholesome . . . " 37 Currie conceded that a state's choice of law rules also express a policy, but argued that it was a policy of a much lower order than the social and economic policies of laws that are directly designed to further the concerns of the government and the people. ${ }^{38}$

From these premises Currie concluded that, given a legitimate interest in its application, forum law must be applied irrespective of any countervailing interest of some other jurisdiction, even though such a competing interest might be superior. In later writings, however, he urged courts to exercise restraint and moderation in finding a forum interest, and a modicum of altruism in recognizing competing interests of other states. ${ }^{39}$

Only the brilliance of Currie's writing can explain the acceptance of the idea of compelling governmental interests. Apart from the unappealing nature of the beggar-thy-neighbor principle, ${ }^{40}$ his teachings ignore the experience of centuries. Ever since conflicts law first developed, courts did precisely what Currie would forbid them to do; no judge has ever been impeached for inventing or applying a choice of law rule that sacrifices forum interests. Even in jurisdictions such as France, where strong views on the separation of powers are held, judges

35 CURRIE 190.

$36 I d$. n.5.

37 Id.

38

A choice-of-law rule does express a policy, but it is not of the same order as the social and economic policies which are normally developed by a state in the pursuit of its governmental interests and the interests of its people. . . [T] ] policy is that the state, as a member of the community of states, will join in a fairly general movement that imposes a degree of restraint upon its sovereignty and upon the pursuit of its selfish interests . . . This is but a mild, tentative, and self-denying policy.

Id. 52-53.

39 See notes 19-20 supra.

40 Currie tends to personify states, attributing to them such characteristics as selfishness and sacrifice. See, e.g., Currie 53, 89, 112, 180. 
have manufactured conflicts law in full view of complacent legislatures. ${ }^{41}$ When legislatures chose to deal with the subject, they enacted rules similar to those previously developed by judges. The postulate of judicial impotence seems peculiarly inappropriate in tort law, since the pervasive policies underlying substantive law in that area are largely the creatures of judicial lawmaking:

It is not surprising, therefore, that courts on the whole have tended to decide tort choice of law cases on grounds broader than those suggested by Currie, ${ }^{42}$ even though a definite tendency to apply forum law is discernible. ${ }^{43}$ In fact, the manner in which they attempt to balance interests and policies of the various jurisdictions in multistate tort cases ${ }^{44}$ cogently demonstrates the power and competence of common law judges to deal freely with such commodities.

\section{B. Functional Analysis}

Ehrenzweig, himself an advocate of the expanded application of forum law, and Rheinstein have seriously questioned whether a state has much of an interest in effecting the policies underlying its private law. ${ }^{45}$

Although there is no verification of the existence of such interests, a substantial number of courts nevertheless accept the term "interests," 46 (or its equivalent "concerns" ${ }^{47}$ ) as a key term of choice of law analysis. That judges like these words is understandable in view of the frequency with which the Supreme Court and other tribunals

41 See H. Batiffor, Droit International Prive 20-21 (4th ed. 1967). In other civil law countries as well, conflicts law is largely judge-made. See 1 E. RABEL, THE Conflict of Laws: A Comparative Study 42-43, 45 (2d ed. 1958).

42 See note 26 supra \& accompanying text; R. LefLAR, AMERICAN Conflicts LAw 328 (rev. ed. 1968) [hereinafter cited as LEFLAR].

43 Of the 15 cases cited in note 2 supra, 14 applied the lex fori.

44 See, e.g., Gore v. Northeast Airlines, Inc., 373 F.2d 717 (2d Cir. 1967) ; Reich v. Purcell, 67 Cal. 2d 551, 432 P.2d 727, 63 Cal. Rptr. 31 (1967); Griffith v. United Air Lines, Inc., 416 Pa. 1, 203 A.2d 796 (1964); Wilcox v. Wilcox, 26 Wis. 2d 617, 133 N.W.2d 408 (1965).

45 A. Ehrenzweig, Conflict of Laws 350 (1962) [hereinafter cited as EnrenzWeig, Treatise]; A. EgrenzWeig, Private International LaW 63 (1967) [hereinafter cited as Errenzwerg, P.I.L.] ; Rheinstein, Book Review, 11 AM. J. CoMp. I. $632,657-58,664$ (1962). But see Baade, supra note 23, at 147-49. Cavers finds the concept dispensable. CAvers 102 . Weintraub believes that "no harm results" if the word is used to distinguish current analysis from territorially oriented choice of law rules. Weintraub, in Comments on Reich v. Purcell, 15 U.C.L.A.L. REv. 556 (1968); see note 90 infra.

46 E.g., Reich v. Purcell, 67 Cal. 2d 551, 432 P.2d 727, 63 Cal. Rptr. 31 (1967); Wartell v. Formusa, 34 I1l. 2d 57, 213 N.E.2d 544 (1966) ; Babcock v. Jackson, 12 N.Y.2d 473, 191 N.E.2d 279, 240 N.Y.Y.S.2d 743 (1963).

47 E.g., Kopp v. Rechtzigel, 273 Minn. 441, 141 N.W.2d 526 (1966) ; Babcock v. Jackson, 12 N.Y.2d 473, 191 N.E.2d 279, 240 N.Y.S.2d 743 (1963). 
employ them. ${ }^{48}$ However, courts and legal writers who adopt Currie's terminology do not necessarily share his conclusions. Rather, they favor a "functional" analysis ${ }^{49}$ which attempts to reconcile or accommodate the conflicting interests of the several states involved in a multistate transaction. Arguably, Currie himself fell in this category when he changed his initial position and counseled moderation and restraint in ascertaining forum policies and interests. ${ }^{50}$ Once courts are free to restrain and moderate they can exercise the very discretion to sacrifice forum interests which Currie originally said they did not have.

This shift from unilateral assertion to accommodation has deprived the concept of governmental interests of its substance. The degree to which it has become emasculated is apparent when one considers that, according to Cavers's interpretation, Currie's terminology merely embodies

a conclusion that the purposes of a statute or common-law rule would be advanced by its application . . . . Since the rule emanates from the state, . . . the rule's purposes may reasonably be ascribed to the state . . . .

... [I]t [is] reasonable to ascribe to the state a desire to have the purposes of its laws effectuated . . . . ${ }^{51}$

So conceived, the word "interest" no longer connotes an affirmative, viable aspect of governmental endeavor. It has become a mere figure of speech which expresses the doubtful assumption that states "desire" to have their laws applied in preference to the laws of other jurisdictions, an assumption which finds no firmer support than the bare fact that a statute was once passed or a common law rule left unchanged. Stripped of their trimmings, "governmental interests" appear no less fictitious than the metaphoric vesting of rights. What remains is the idea that

${ }^{48}$ See, e.g., cases cited note 29 supra.

The Supreme Court cases in particular seem to use the term "interests" merely to embody the conclusion that under the circumstances it was not unreasonable to apply forum law. The Court could have justified this conclusion by simply looking to the contacts. See LEFLAR 137:

Courts deciding conflicts cases have as often as not accompanied their references to factual contacts in a state with references to the local concerns or interests which grew out of these contacts . . . . Comparable language undertaking to identify social, political, economic, and even cultural interests attributable to a state because of the incidence of local factors in a litigated case has been employed hundreds of times.

49 The current use of this term in the conflicts setting was promoted primarily by its use in A. von Menren \& D. Trautman, THe Law of Multistate Problems (1965). It is used here to differentiate Currie's approach from that adopted by most courts and writers.

50 See note 34 sipra; CAvers 73; EHRENzwerg, P.I.L. 64-65. See also Traynor, Confict of Lazus: Professor Currie's Restrained and Enlightened Forum, 49 CALIF. L. REv. 845 (1961).

51 Cavers 100. 
a proper approach to choice of law must take into account the policies underlying competing substantive rules in a multistate situation, which policies are assumed to have a bearing on the spatial reach of the rules.

In conflicts law, as elsewhere, the words "policy," "interest," "purpose," or "legislative intent" are invoked to justify a result that does not follow from the letter of the law. They are devices used to expand or contract a rule, while at the same time professing faithfulness to its tenets. According to Currie, "[ $t]$ he process of defining policy and interest is the process of construction and interpretation . . . " 52 However, he conceded that when courts or legislatures coin a substantive rule, they generally give no thought to its territorial purport. ${ }^{53}$ One should conclude that the bare existence of a law cannot serve as the basis for any inference concerning its spatial reach, other than that the "lawmaker intended" 54 to have it apply within the limits of existing or future choice of law rules. Instead, the policy analysts substitute their own judgment about the reasonable reach of the law for a nonexistent legislative intent. ${ }^{55}$ This judgment is most frequently based on some form of personality principle. ${ }^{56}$ Thus, in his pilot article on married women's contracts, Currie assumed that the Massachusetts law denying contractual capacity was obviously designed to protect Massachusetts wives. ${ }^{57}$ However, the policy underlying the disability not only antedates nation-states and the Commonwealth of Massachusetts, but had a much more universal purport. ${ }^{58}$ Quite generally, the idea that laws exist merely for the benefit and protection of subjects seems strangely at odds with the reaiities of twentieth century America. The interest

E2 CURRIE 604.

53 See id. 82; Reese, Conflict of Lazes and the Restatement Second, 28 LAW \& Contenr. Prob. 679, 686 (1963).

54 Compare Radin, Statutory Interpretation, 43 HARv. L. REv. 863 (1930), with Landis, $A$ Note on "Statutory Interpretation," 43 HARv. L. Rev. 886 (1930).

55

[T] he legislature never thought about the matter at all. Hence a court following this approach must inquire what the legislature would have intended, or should have intended, had it thought about the problem. Since the court will naturally assume that the legislature was composed of reasonable men, it will almost inevitably suppose that the legislature would have been moved by the same considerations as would have moved the court. . . .

[A] court that adheres to .... [this] approach will pretend to be effectuating the intentions of the legislature.

Reese, supra note 53, at 686.

See also Cavers 96-97; Leflar 229-30. The latter states that this "pseudo-interpretative process" is, in fact, an application of standard choice-of-law considerations.

56 See, e.g., Cavers 134-36.

57 "What married women? Why, those with whose welfare Massachusetts is concerned, of course-i.e., Massachusetts married women." CuRRIE 85.

58 See generally P. BRoMLEy, FaMily LAw 271-78 (3d ed. 1966); J. Madden, Handbook on the LaW of Persons and Damestic Recations 96-98 (1931). 
states may have in the application of rules of private law and the policy underlying such rules, hopefully, is to see justice done ${ }^{59}$ and to protect the "welcome visitor." 60

Considerations of a more practical nature also suggest that an analysis based on policies and purposes does not offer a satisfactory basis for the resolution of tort choice of law problems. The difficulties that accompany the litigation of foreign law issues ${ }^{61}$ would be compounded by the added requirement of having to establish foreign policies as well as foreign rules. Often a rule does not reflect a clear-cut policy, ${ }^{62}$ or is the result of a compromise between conflicting policies. ${ }^{63}$ Use of such vague terminology invites courts to take short cuts and make ad hoc decisions since "some reasons, usually a variety of them, can be called up in support of almost any rule of law . . . ." 64 Since the functional approach implies that policies of conflicting rules are weighed and balanced for each issue, and since it looks to policies in addition to those abstracted from domestic rules, these practical diffculties are exacerbated.

If an analysis of policies is called for, one might ask why this analysis should not concentrate on the policies embodied in choice of law rules. ${ }^{05}$ They are the only rules specifically designed to effectuate any interests that a state may have in the application of its law in multistate situations. If such rules are statutory, as they are in many countries, a court must apply them. If they are judge-made, they are the best evidence of what courts have thought to be the most appropriate solution of conflicts problems. As noted earlier, from the point of view of "legislative intent," the indifference of most legislatures can be interpreted as deference to judicial wisdom, unless one excludes the possi-

59 Scoles, in Comments on Reich v. Purcell, 15 U.C.L.A.L. REv. 563, 567 (1968).

60 Leflar, in Comments on Reich v. Purcell, 15 U.C.L.A.L. Rev. 637, 639 (1968).

61 See Rheinstein, supra note 45, at 663 . The difficulties in ascertaining and establishing foreign law are vividly discussed in CURRIE 3-76, commenting on Walton v. Arabian Am. Oil Co., 233 F.2d 541 (2d Cir.), cert. denied, 352 U.S. 872 (1956).

62 See CURRI 608-09. He suggests "[i]n all solemnity" that if there are laws that do not express any governmental policy, the law of the state first in alphabetical order should be selected.

63

Even the simple rules that raise rights and duties with regard to personal injuries are a composite of thrusts and counter-thrusts of many kinds. . . To try to bring all of the huffing and puffing together into a policy that runs clearly in one direction and that has a measurable intensity that permits comparing it with some contrary policy is . . . pure fantasy.

Rosenberg, in Two Views on Kell v. Henderson, An Opinion for the New York Court of Appeals, 67 Colum. L. REv. 459, 464 (1967).

64 Leflar 252. He also notes that "it is nearly always possible for a good lawyer to conjure up governmental interests in just about any state that has any connection with a set of facts." Id.

65 "All, rules of law, and choice-of-law rules are no exception, are the product of policies." Reese, supra note 53 , at 681 . 
bility that conflicts law expresses a policy or assumes that such policy is inferior to all others, ${ }^{66}$ an assumption which would be difficult to justify considering the remarkable agreement throughout the world on the necessity for conflict of laws rules. ${ }^{67}$

\section{False Conflicts}

Common to both of the above approaches is the notion of "false conflict." es This term would be unobjectionable if used to describe a multistate situation in which the laws of all of the states with which a transaction has contacts are identical, or in which application of any of the laws would lead to the same result. In such a case the conflict would be "false" in the sense that it would not be necessary to make a determination which of these laws should be applied. ${ }^{69}$ It may be noted, however, that there is no general agreement among the courts ${ }^{70}$ or legal writers ${ }^{71}$ that in these situations the result should be the same as that which would follow from any of the potentially applicable laws.

Yet the meaning of "false conflicts" as employed by the interest and functional analysts is another one. They use these words to refer to cases "in which the governing rule may be drawn from the domestic substantive law of one state, thus advancing its underlying policy, without frustrating any applicable policy of another jurisdiction involved in the case." 72 So construed, the words in effect "describe the choice of law process itself . . . . [a]nd in . . . other cases . . . situations in which choice of law has already been made." 73

60 See note 38 supra.

67 If this proposition needs a citation, there is hardly a more appropriate one than the four volume masterpiece, E. RaBEL, The Conflict of LAWs: A CoMparative STUDY (2d ed. 1958).

68 The terminology varies. Cavers referred to "false problems," in contradistinction to "true conflicts." Others speak of "no conflicts," "spurious conflicts," "illusory conflicts," "apparent conflicts," "avoidable conflicts," "pseudo conflicts" or "superficial conflicts." For a discussion of these terms and their applications, see Comment, False Conflicts, 55 CALIF. L. REv. 74, 76 (1967).

69 See Lefrar 239.

70 See Scheer v. Rockne Motors Corp., 68 F.2d 942 (2d Cir. 1934) ; Lillegraven v. Tengs, 375 P.2d 139 (Alas. 1962); Dalton v. McLean, 137 Me. 4, 14 A.2d 13 (1940); Marie v. Garrison, $13 \mathrm{Abb}$. N. Cas. 210 (N.Y. Super. Ct. 1883). Modern writers are not necessarily in disagreement with such decisions. See CAvers 39,41,310-11; Wilde, Depeçage in the Choice of Tort Law, 41 S. CAL. L. REv. 329 (1968); Comment, supra note 68 , at 96-100, 105-16.

71 If choice of law rules or methods permit "severability" or "splitting" of issues, i.e., the application of the law of more than one state to different issues of the same case, see LEFLAR 348-49, the breeding of teratoid hybrids, see CAvERS 311, and similar creatures of a never-never law can hardly be avoided. Unless choice of law is conceived in jurisdiction-selecting terms, plaintiff's claim "can fall between two stools," or the law may "put together half a donkey and half a camel" and permit him to "ride to victory on the synthetic hybrid," two alternatives of which Currie liked only the first. See Cavers 39.

72 Gorman, Book Review, 115 U. PA. L. Rev. 288, 291-92 (1966).

73 Comment, supra note 68, at 122 . 
A number of courts have used the latter meaning of false conflicts to decide cases. ${ }^{74}$ But conflicts are only false if policies and interests are true. It has been shown convincingly that where potentially applicable laws differ, analysis in terms of false conflicts amounts to an after-thedecision technique. ${ }^{75}$ It presupposes agreement on the proper method of analysis, on the means used to discern interests and policies, and on their significance and spatial purport. Thus, it has relevance and utility only for those committed to a given method. ${ }^{76}$

\section{The Most Significant Relationship}

In view of the many critical comments that have already been made about the provisions of the Second Restatement in general and its tort provisions in particular, ${ }^{77}$ little more need be said about the most significant relationship test, the criterion which the present Restatement of Conflicts proposes to use to determine which state's law to apply. ${ }^{78}$ Although it is printed in black letters, section 145 is not much of a rule ${ }^{79}$ since it fails to offer a definition of the central word "significant." Thus, the Restatement provisions on tort choice of law appear to be programmatic rather than normative. ${ }^{80}$ They emphasize freedom of

74 See, e.g., cases cited note 12 supra.

75 Leflar 238-39.

76

The concept of "false conflicts" enjoys protean facility for justifying everyman's choice-of-law theory . . .

To speak of governmental-interest analysis as a "workable means of identifying" false conflicts is to suggest that false conflicts "exist" somehow independently from the process which establishes them. To the extent that a finding of false conflicts is a product of governmental-interest analysis, it is both improper and misleading to divorce that finding from the process which creates it.

Comment, supra note 68, at 78-79.

77 See, e.g., D. Cavers, The Choice of Law Process 69-72 (1965) [hereinafter cited as Cavers]; B. Currie, Selected Essays on the Conflict of Laws 594-96 (1963) [hereinafter cited as CuRrIE]; Ehrenzweig, Treatise 351, 364; EHREN2weig, P.I.L. 66-68, 73; Comment, The Second Conflicts Restatement of Torts: $A$ Caveat, 51 CALIF. L. REv. 762 (1963).

78 Restatement (Second) of Conflict of Laws $\$ 145$ (Proposed Official Draft, part II, 1968).

79

The rule of most significant relationship is undoubtedly too vague to offer firm guidance in situations where the important contacts are divided more or less equally among two or more states. It is believed, however, that no more definite rule can be stated in view of the relatively unexplored state of the field and the existing confusion among the authorities.

Reese, Conflict of Laws and the Restatement Second, 28 LAW \& ConTEMr. Prob. 679, 697 (1963).

80

This rule of most significant relationship, at the very least, will not stand in the way of progress. It should aid in inducing the courts to depart from the place of injury rule in situations where this is desirable. And it should make clear to the lawyer and litigant that it can no longer be expected that the Id. 699. place of the injury rule will always be applied. 
the courts from the compulsion of fixed rules and encourage them to apply the law which they think has the strongest claim for application. This may in fact be the best description of what many courts are doing. It corresponds to the verbal formula used in Babcock and in several other cases. $^{81}$

This formula is perhaps the most poignant admission of unrestatability. ${ }^{82}$ Furthermore, the necessity of focusing on contacts and their relative importance may have the effect of inhibiting courts from setting forth explicitly the factors that induced them to adopt a given resolution.

Section 6(2) of the new Restatement, ${ }^{83}$ incorporated in section 145 by reference, and the discussion in the comments following that section reflect the terminology and thinking of interest analysis. Perhaps such an amalgamation was deemed necessary to give some substance to the term "significant." But it places in doubt the extent to which the Restatement's proper law test offers anything unique or distinct from interest methodology.

At best, the Restatement provisions restate the lack of certainty prevailing in tort choice of law. At worst, the adoption of such openended provisions by the American Law Institute may serve to perpetuate the current uncertainty and to inhibit the search for alternative solutions to tort choice of law problems.

\section{E. Choice-Influencing Considerations}

A number of authors have attempted to state the purposes and desiderata of conflicts law and have enumerated "choice-influencing considerations." Cheatham and Reese ${ }^{84}$ listed nine which found their way into section 6 of the Draft Restatement in a somewhat modified form. Yntema mentioned seventeen factors, but concluded that the essential policy considerations of conflicts law could be reduced to two

81 Merchants Nat'l Bank \& Trust v. United States, 272 F. Supp. 409 (D.N.D. 1967); Schwartz v. Schwartz, 103 Ariz. 562, 447 P.2d 254 (1968); Fabricius v. Horgen, 257 Iowa 268, 132 N.W.2d 410 (1965) ; Casey v. Manson Constr. \& Eng't Co., 247 Ore. 274, 428 P.2d 898 (1967); Griffith v. United Air Lines, Inc., 416 Pa. 1, 203 A.2d 796 (1964).

82 Compare Reese, supra note 79, at 681 :

Choice of law, even now, is not ripe for restatement in the sense that it is rarely possible to state hard and fast rules with the reasonable assurance based on precedent and the resources of human reasoning and imagination that these rules will work well in all situations to which they literally can be applied.

83 Restatement (Second) of Confitct of Laws $\$ 6$ (2) (Proposed Official Draft, part I, 1967).

84 Cheatham \& Reese, Choice of the Applicable Law, 52 Colum. L. Rev. 959 (1952). See also Reese, supra note 79. 
categories-security and comparative justice. ${ }^{85}$ Current judicial opinions relying on such factors ${ }^{86}$ generally use the formulation by Leflar, who reduced the list to five considerations. ${ }^{87}$

Leflar conceives of these factors as a means to test the results and the reasoning of judicial decisions, rather than as rules. ${ }^{88}$ In essence, his list is a recognition of the freedom judges have in making choice of law decisions, as well as an exhortation to them not only to be frank about stating the considerations actually used, but to reach results compatible with those considerations. ${ }^{89}$ This method is also open to the challenge that it does not provide sufficient certainty. But at least it has dual merit in that it inspires judicial candor and, except for its somewhat grudging recognition of governmental interests, frees judges from the need to resort to shibboleths and dogma. Moreover, it tends to emphasize that courts in conflicts cases are called upon to adjudicate private disputes, rather than to arbitrate the claims of sovereigns. ${ }^{90}$

\section{Appitcation of Current Methodologies in Practice}

For the most part, the cases that have spawned the conflicts revolution involved automobile and airplane accidents, ${ }^{91}$ that is, situations in

85 Yntema, The Objectives of Private International Law, 35 CAN. BAR REV. 721, 734-35 (1957).

80 See Tiernan v. Westext Transport, Inc., 295 F. Supp. 1256 (D.R.I. 1969); Schneider v. Nichols, 280 Minn. 139, 158 N.W.2d 254 (1968); Mitchell v. Craft, 211 So. 2d 509 (Miss. 1968); Clark v. Clark, 107 N.H. 351, 222 A.2d 205 (1966); Conklin v. Horner, 38 Wis. $2 d$ 468, 157 N.W.2d 579 (1968).

87

(A) Predictability of results;

(B) Maintenance of interstate and international order;

(C) Simplification of the judicial task;

(D) Advancement of the forum's governmental interests;

(E) Application of the better rule of law.

LEFLAR 243-45.

88

Obviously, the considerations do not furnish rules of thumb .... Wiser judicial opinions and more thoughtful analysis of the relevant reasons for decision may be expected if the considerations are given proper weight . . . .

Id. 259.

89 Leflar indicates that the relative importance of the 5 factors varies according to the case before the court. IEFLAR 245 .

90 Trautman states:

[C]onflicts problems involve more than a clash between governmental interests, and the opinion [in Reich $v$. Purcell] takes great care to avoid anthropomorphizing the concerned jurisdictions. For California, Missouri, and Ohio are not at war here, nor even are there conflicting rules designed to further the interests of the governments of those states. Involved are simply rules of recovery for wrongful death regarded by those states as appropriate for adjusting claims among individuals . . . The current obsession with analysis in terms of governmental interests is usefully ignored by the court, which again and again speaks ... of the interests of the individual litigants.

Trautman. in Comments on Reich v. Purcell, 15 U.C.L.A.L. REv. 618, 623 (1968).

91 Of the 15 cases cited in note 2 supra, 14 involved automobile accidents and one involved an airplane mishap. 
which the application of traditional tort rules and modes of procedure has become increasingly controversial. ${ }^{92}$ Congested courts ${ }^{93}$ and fluctuating awards ${ }^{84}$ are but two symptoms of the high social costs ${ }^{95}$ which tort law presently exacts. The introduction of modern conflicts thinking into this area superimposes complexity on already vexing problems. ${ }^{96}$

Consider, for example, the case of Kell $v$. Henderson, ${ }^{97}$ which involved the converse factual pattern of that presented in Babcock. Two Ontario parties, a driver and passenger, had an automobile accident in New York, the forum state. At issue was the applicability of the Ontario guest statute (the same issue presented in $B a b c o c k$ ). If a judge were to follow one suggested approach in order to decide the case, ${ }^{98}$ he

92

[T] he fault system is little more than an immoral lottery for both plaintiffs and defendants . . . it is totally out of date as a reparation device.

Franklin, Replacing the Negligence Lottery: Compensation and Selective Reinbursement, 53 VA. L. REv. 774, 778 (1967). See Ehrenzweig, P.I.L. 74 n.124.

One barometer of the current controversy is the hue and cry which has been raised over the compensation-without-regard-to-fault doctrine embodied in the Keeton-O'Connell plan. See Institute of Continuing Legal Education, Protectron for the Traffic Victim: The KeEton-O'Connelt Plan aNd Its Critics (1967); Trial, Oct.-Nov., 1967, at 12-54. See also L. GreEn, Traffic Victims: TORT LAW AND INSURANCE (1958); Berger, Compensation Plans for Personal Injuries, 1962 U. Inx. L.F. 217; Ehrenzweig, "Full Aid" Insurance for the Traffic Victim-A Voluntary Compensation Plan, 43 CALIF. L. REv. 1 (1955); Marx, A Nere Approach to Personal Injury Litigation, 19 OHIO StaTE L.J. 278 (1958); Marx, Let's Compensate-Not Litigate, 3 FEDERATION OF INS. COUNSEL Q. 62 (1953); A Symposizm in Honor of Charles O. Gregory, 53 VA. I. REv. 774 (1967) (articles by Franklin, Fleming, Ehrenzweig, Goodhart, Paulsen, Keeton, Morris \& James).

These authors were primarily concerned with automobile accidents. However, a similar controversy rages with respect to air law. See, e.g., Vold, Strict Liability for Aircraft Crashes and Forced Landings on Ground Victinns Outside of Established Landing Areas, 5 Hastrngs L.J. 1 (1953); Sweeney, Is Special Aviation Liability Legislation Essential? (pts. 1-2), 19 J. AIR L. \& CoMr. 166, 317 (1952).

${ }^{93}$ See H. Zeiser, H. Kalven \& B. Bucholz, Delay in the Court (1959).

94 Conard, The Economic Treatment of Automobile Injuries, 63 Micr. L. Rev. $279,291-92$ (1964). In 2 recent cases, recovery was limited to the Brazilian statutory maximum of 100,000 cruzeiros (less than $\$ 175$ ). Tramontana v. S.A. Empresa de Viacao Aerea Rio Grandense, 350 F.2d 468 (D.C. Cir. 1965), cert. denied, 383 U.S. 943 (1966); Ciprari v. Servicios Aereos Cruzeiro, 245 F. Supp. 819 (S.D.N.Y. 1965). 95 Green, supra note 92, at 81-82.

96

[W] must watch uneasily while one victim extracts unheard-of sums in damages for harm inflicted on him by one of the unavoidable hazards of modern enterprise, and thousands of others go uncompensated because they cannot or will not go through the gamble, delay and perjury attending the search for and proof of "fault" and "foreseeable" harm. In the meantime too, we must watch uneasily while some victims of an air crash recover hundreds of thousands of dollars in one state while victims of the same crash recover a mere trifle in another. No wonder that in multistate cases judges, faced with a choice between such widely and unaccountably differing, yet equally inadequate laws, have despaired

Ehrenzweig, "False Conflicts" and the "Better Rule": Threat and Promise in Multistate Tort Law, 53 VA. L. REv. 847, 847-48 (1967) (footnotes omitted). See also Kinney, The Interstate Aviation Accident-What Law Governs, 31 INs. CounsEL J. 250 (1964).

9726 App. Div. 2d 595, 270 N.Y.S.2d 552 (1966).

98 See Trautman, A Comment, in Two Views on Kell v. Henderson, 67 Couus. I. REv. 459,465 (1967). 
would not only have to cope with the intricacies of a foreign guest statute, ${ }^{99}$ but he would also have to analyze the policies underlying that statute, ${ }^{100}$ plus the general tort law ${ }^{101}$ of the concerned ${ }^{102}$ jurisdictions, and to assess their relevance to the multistate problem. If the policies conflict, he must suppress his instinctive forum preference. He may, however, impeach the policy of the foreign guest statute by means of an inquiry into its history, and he may scrutinize the cases and the law review articles that either interpret or otherwise shed light on it. $\mathrm{He}$ cannot eschew unpublished ${ }^{103}$ and apocryphal ${ }^{104}$ matter, legislative studies and proposals, and pertinent statistics, for if this research indicates that guest statutes in general, and the foreign one in particular, are somewhat dated, he will be free to apply the law of the forum (which he could have applied in any event).$^{105} \mathrm{He}$ may do so because an obsolete foreign policy does not amount to a "real" policy even if the foreign courts keep effectuating it. ${ }^{106}$ However, if the judge, during

99

There is perhaps no other group of statutes which have filled the courts with appeals on so many knotty little problems involving petty and otherwise entirely inconsequential points of law.

W. Prosser, HANDBook ON THE LAW OF TORTS \$ 34, at 191 (3d ed. 1964).

100 The New York Court of Appeals stated that these policies were the prevention of collusion, and the protection of insurance companies. Babcock v. Jackson, 12 N.Y.2d 473, 191 N.E.2d 279, 240 N.Y.S.2d 743 (1963). But Dym v. Gordon, 16 N.Y.2d 120, 209 N.E.2d 792, 262 N.Y.S.2d 463 (1965), also suggested a "trust fund" theory, i.e, priority of recovery by third parties that might be hurt. This raises the interesting question whether policies change with the factual situation.

101 The torts policies cited were "compensation, admonition, deterrence, and perhaps even retribution." Trautman, supra note 98, at 466 . As authority for these policies Trautman cites Williams, The Aims of the Law of Tort, 4 Currenr LEGAL Prob. 137 (1951). He does not indicate whether New York and Ontario (the two "concerned" jurisdictions) recognize any, either, or all of these policies as their policies, and, if so, whether they accord them equal weight. Clearly, it would be too much to assume that all tort laws everywhere have the same policies.

102 Trautman found a New York concern because

[i]t is not wholly irrational for New York to impose liability for negligent conduct on its highways which might, although on these facts did not, involve the safety of third parties, motorists, or pedestrians, on New York highways. Admonitory and deterrent policies legitimately come into play. And it cannot be denied that New York regards compensation as important, so that a policy of giving evenhanded nondiscriminatory treatment with compensation to all persons injured in New York would justify extension of its concern to Ontario people if no contrary Ontario policy is found to exist.

Trautman, supra note 98 , at 467.

103 See the reference to materials Professor Trautman was furnished by a Canadian colleague. Trautman, sipra note 98 , at 470 .

104

[T]he Premier of Ontario was receptive to the guest statute because he personally had suffered the ingratitude of a pair of hitch-hikers who had sued him successfully.

Id. (citing Linden, Comment, 40 CAN. BAR Rev. 284, 286 n.11 (1962)).

105 The full faith and credit clause is inapplicable because the statute involved is not that of a sister state, and the Supreme Court has held that there is no constitutional problem in applying the lex loci delicti because the state where the tort occurs has a concern. Carroll v. Lanza, 349 U.S. 408 (1955); accord Pacific Employers Ins. Co. v. Industrial Accident Comm'n, 306 U.S. 493 (1939). 106 See Gagnon v. Lecavalier, [1967] 2 Ont. 197. 
his research, is overcome by mental fatigue and believes that this effort to reach a rational solution is too complex, he can simply abandon it. ${ }^{107}$

Esthetics alone militates against the application of such heavy apparatus to the facts in Kell. Courts have not gone quite as far. But the economic waste inherent in the new methodology is apparent if one reads some of the overwrought opinions ${ }^{108}$ it produces, and considers how little guidance these end products of protracted lawsuits furnish to other parties, insurance companies, adjusters, counsel, or judges. In consequence, any interstate element has the propensity for converting a run-of-the-mill accident into a cause célèbre of baffling complexity. Judges and lawyers must scrutinize each factual aspect, such as the location of the garage, ${ }^{109}$ the purpose of the sojourn, ${ }^{110}$ the occupation of the parties, ${ }^{111}$ the place of boarding the car, ${ }^{112}$ family ties, ${ }^{113}$ the color of the license plates, ${ }^{114}$ the name of the insurer and the place where the policy was written, ${ }^{115}$ for its potential legal significance, however innocuous it may seem at first blush. A collision case further complicates their task, as does the fact that the medium of disaster happened to be a common carrier. ${ }^{116}$ Litigation is encouraged, and the likelihood of appeals and remands is increased. In sum, the parties pay more for "flexibility" than they used to pay for rigidity.

107 Trautman, supra note 98 , at 473.

108 See, e.g., Gore v. Northeast Airlines, Inc., 373 F.2d 717 (2d Cir. 1967) ; Dym v. Gordon, 16 N.Y.2d 120, 209 N.E.2d 792, 262 N.Y.S.2d 463 (1965); Casey v. Manson Constr. \& Eng'r Co., 247 Ore. 274, 428 P.2d 898 (1967); Griffith v. United Air Lines, Inc., $416 \mathrm{~Pa} .1,203$ A.2d 796 (1964). Looking through these cases, one cannot help but wonder whether the parties ever had occasion to read any of them. To the layman, such opinions must sound like a mockery of the loser's plight, if not of justice. 100 See Mellk v. Sarahson, 49 N.J. 226, 229 A.2d 625 (1967) ; Babcock v. Jackson, 12 N.Y.2d 473, 191 N.E.2d 279, 240 N.Y.S.2d 743 (1963).

110 See, e.g., Schneider v. Nichols, 280 Minn. 139, 146, 158 N.W.2d 254, 259 (1968) ; Dym v. Gordon, 16 N.Y.2d 120, 209 N.E.2d 792, 262 N.Y.S.2d 463 (1965). 111 See Armstrong v. Armstrong, 441 P.2d 699, 703 (Alas. 1968).

112 See, e.g., Duffy v. Currier, 291 F. Supp. 810, 815 (D. Minn. 1968) ; Schneider v. Nichols, 280 Minn. 139, 145, 158 N.W.2d 254, 257 (1968).

113 Macey v. Rozbicki, 18 N.Y.2d 289, 221 N.E.2d 380, 274 N.Y.S.2d 591 (1966). 114 See Kopp v. Rechtzigel, 273 Minn. 441, 141 N.W.2d 526 (1966) ; Babcock v. Jackson, 12 N.Y.2d 473, 191 N.E.2d 279, 240 N.Y.S.2d 743 (1963).

115 See, e.g., Johnson v. Johnson, 107 N.H. 30, 32-33, 216 A.2d 781, 783 (1966); Conklin v. Horner, 38 Wis. 2d 468, 157 N.W.2d 579 (1968).

116 The place where the carrier is registered to do business, see, e.g., Long v. Pan American World Airways, Inc., 16 N.Y.2d 337, 341, 213 N.E.2d 796, 798, 266 N.Y.S.2d 513, 516 (1965); Griffith v. United Air Lines, Inc., 416 Pa. 1, 203 A.2d 796 (1964), and the place where the contract was made, see, e.g., Gore v. Northeast Airlines, Inc., 373 F.2d 717, 724 (2d Cir. 1967) ; Kilberg v. Northeast Airlines, Inc., 9 N.Y.2d 34, 38, 172 N.E.2d 526, 527, 211 N.Y.S.2d 133, 134 (1961), became relevant factors. In addition, the very fact that there was a contract of carriage (as opposed to the gratuitous host-guest relationship found in many of the automotive cases) poses the additional problem whether the suit should be brought in trespass or assumpsit. See, e.g., Kilberg v. Northeast Airlines, Inc., 9 N.Y.2d 34, 172 N.E.2d 526, 211 N.Y.S.2d 133 (1961) ; cf. Griffith v. United Air Lines, Inc., 416 Pa. 1, 203 A.2d 796 (1964); Scott v. Eastern Air Lines, Inc., 399 F.2d 14 (3d Cir.), cert. denied, 393 U.S. 979 (1968). 
The consequences of applying current methodologies in practice have been strongly criticized. Rosenberg, commenting on Kell $v$. Henderson, said, "The bar and lower courts are flabbergasted by [Babcock v. Jackson]. A New York lawyer with a guest statute case has more need of an ouija board today than a copy of Shepard's citations." ${ }^{117}$ Noting the ill effects that uncertainty may produce, Rosenberg later wrote:

Wrongful death actions arising from highway accidents are, unfortunately, commonplace events. The law may not deal with them as if they were rare and esoteric conundrums, conceived for the titillation of philosophers and far removed from real world concerns. Scholars, in their fascination with conflicts, should not forget that the game is not being played so they can flex their jurisprudential muscles, but in order to better the human condition through law. ... .

The responsibility of conflicts specialists is to devise as good a system as possible for resolving multistate road accident problems. At a minimum, their duty is to assure that the law does not add legal chaos to the great human tragedy of a fatal collision. ${ }^{118}$

These thoughts are echoed by others. ${ }^{119}$ In a more understated fashion, one of the exponents of modern methodology has expressed his uneasiness with the state of the case law:

My own efforts and my observation of the efforts of contemporary courts and scholars to extract guidance for choice of law from the purposes of the forum's and the other state's laws have convinced me that the process is more difficult than Professor Currie's advocacy would lead one to believe.

The problem we face today is not how to exorcise choice of law rules and principles but how to develop them. ${ }^{120}$

The crux of the matter is that the abandonment of the safety and comfort of conventional wisdom has led to a dual fragmentation: proliferation of connecting factors and splitting of issues. This poses no insurmountable problem as long as criteria are made available to determine which of these factors is paramount with regard to each

117 Rosenberg, An Opinion for the New York Court of Appeals, in Two Views on Kell v. Henderson, 67 ColuM. L. REv. 459, 460 (1967).

118 Rosenberg, in Comments on Reich v. Purcell, 15 U.C.L.A.L. Rev. 551, 641, 644-45 (1968).

119 See authors cited note 24 supra.

120 Cavers 108, 113. 
issue. Currie's methodology, which simply favored the forum, could yield results, but any improvement upon this learning (including Currie's own), ${ }^{121}$ that seeks to balance or accommodate interests and policies is unworkable. Policies are an elusive matter. They derive "reality" and "significance" only through the predilections of the decision-maker; yardsticks have never been devised to measure them, nor scales to weigh them.

The practical problems posed by the functional approach are illustrated by the graph in Currie's famous article, which depicts how four connecting factors generate sixteen possible combinations in a two-state situation. ${ }^{122}$ The domicile and residence of either party and of their beneficiaries, and the various places of garaging, insurance, licensing, injury, starting and terminating a trip, and entering into a host-guest relationship, have all been recognized as contacts properly taken into account in guest statute cases. ${ }^{123}$ Assuming these contacts are sufficiently divided among three or more states, the mathematics for determining the number of cases necessary to settle the law are depressingly intricate. The expenditure of manpower necessary to litigate these cases is staggering. ${ }^{124}$

This state of affairs is regrettable. The lack of certainty and predictability cannot be justified by the facile argument that torts are generally not premeditated. ${ }^{125}$ The most pressing questions about the law are those asked after the fact. The obfuscation that exists in conflicts law would certainly not be tolerated in substantive tort rules.

The courts that have followed the lure of interest and policy analysis might have done well to consider more carefully the wisdom of ridding themselves of one dogma only to embrace another. The experience with the vested rights theory should have demonstrated the undesirability of burdening the task of decision-making with metalegal speculation. Theories, systems, methods, and approaches have become the bane of tort choice of law. The time seems ripe for administering

121 See notes 34 \& 50 supra \& accompanying text.

122 CURRIE 84.

123 See Baer, Two Approaches to Guest Statutes in the Conflict of Laws: Mechanical Jurisprudence Versus Groping for Contacts, 16 BUFFAzo L. REv. 537, 555 (1967); O'Rourke, Analysis of the Contacts Test: $A$ Numerical Evaluation of Babcock v. Jackson, 11 Prac. Law. 87, 92 (May 1965).

124 Baer cites no less than 40 New York cases which refer to Babcock v. Jackson. A count of the cases listed in Shepard's Citations shows that this number as of July, 1969, grew to over 90 .

125 This unreasoned statement has unfortunately become a favorite with both courts and legal writers. See, e.g., Tiernan v. Westext Transport, Inc., 295 F. Supp. 1256, 1263 (D.R.I. 1969); Clark v. Clark, 107 N.H. 351, 354, 222 A.2d 205, 208 (1966); Zelinger v. State Sand \& Gravel Co., 38 Wis. 2d 98, 108, 156 N.W.2d 466, 470 (1968); R. Leflar, AMIERICAN Conflicts LaW 245-47 (rev. ed. 1968) [hereinafter cited as LEFLAR]; Reese, in Comments on Babcock v. Jackson, $A$ Recent Development in Corflict of Lazes, 63 ColUM. L. Rev. 1251, 1254 (1963). 
a generous injection of pragmatism to a body of law suffering from an overdose of orthodoxies, new and old.

\section{Possible Alternatives}

\section{A. Lex Loci Delicti}

If practicability is the object, resuscitation of the lex loci rule might be the answer. Even though it has been much maligned, this rule is still the law in a majority of jurisdictions, ${ }^{126}$ and the Draft Restatement has not entirely discarded it. ${ }^{127}$ Foreign courts and legislatures with an impressive consensus have opted for some form of lex loci. ${ }^{128}$

Many of the arguments advanced against the rule (seldom in isolation and usually spiked with invective) are unconvincing. To condemn it because it was incorporated into the first Restatement, and was therefore identified with the vested rights theory, ${ }^{120}$ infers guilt from association. In many jurisdictions lex loci prevails, even though the local jurists may never have adopted the vested rights dogma, or may have long rejected it. ${ }^{130}$ In this country, the rule appears to have preceded the doctrine. ${ }^{131}$ Some courts like to characterize the place of accidents that occur in the course of long distance travel as "fortui-

126 Compare 15A C.J.S. Conflict of Laws $\$ 8(4)$ (1967) with id. $\$ 12(2)$. See also 16 AM. JUR. 2d Conflict of Laws \$71 (1964).

127 See Restatement (Second) of Conflict of Laws $\$ 146$ (Proposed Official Draft, part II, May 1, 1968).

128 See generally 2 E. Rabel, The Conflict of Laws: A Comparative Study 235-300 (2d ed. 1960). Rabel lists statutory rules, case law, and legal writers of over 20 nations, as well as treaties. Id. $235-36 \mathrm{n} .20$. The term lex loci delicti commissi as used by Rabel and in the text can refer either to the place of injury or the place of acting. The Restatements selected the place of injury, where conduct and injury occurred in different states. RESTATEMENT OF CONFLICT OF LAWS \&377 (1934) expressed this in the form of a "last event" rule, while RESTATEMENT (SECOND) of CoNflict of LAws \$146 (Proposed Official Draft, part II, May 1, 1968) specifically states that the local law of the jurisdiction where the injury occurred applies. In contrast, European countries tend to favor the place of acting. 2 E. RABEL, THE Conflict of LAws: A Comparative Study 303-04 (2d ed. 1960). See also Ehrenzweig, The Place of Acting in Intentional Multistate Torts: Law and Reason Versus the Restatement, 36 Minn. L. Rev. 1 (1951); Rheinstein, The Place of Wrong: $A$ Study in the Method of Case Laze, 19 TUL. L. REv. 4 (1944).

129 See Restatement (Second) of Conflict of LAws, introductory note at 2 (Proposed Official Draft, part II, May 1, 1968). Concerning the clues to the conflicts philosophy of the Reporter of the first Restatement see D. Cavers, THE Chorce OF LAW PROCESS 6-7 (1965) [hereinafter cited as CAVERS]; Cheatham, American Theories of Conflict of Laws: Their Role and Utility, 58 HARv. L. REv. 361, 365, 385 (1945); Compare Beale, Social Justice and Business Costs-A Study in the Legal History of Today, 49 Harv. L. Rev. 593 (1936).

130 Concerning the fate of the vested rights theory here and abroad see A. EHRENZWEIG, CONFLICT OF LAWS 317-25 (1962) [hereinafter cited as EHRENzWEIG, Treatise]; A. EHRENzWEIG, PRIVATE INTERNational Law 54-62 (1967) [hereinafter cited as EHRENZWEIG, P.I.L.].

131 See, e.g., Davis v. New York \& N.E.R.R., 143 Mass. 301 (1887) ; Nashville \& C.R.R. v. Sprayberry, 67 Tenn. 341 (1874); Needham v. Grand Trunk Ry., 38 Vt. 294 (1865). 
tous," 132 a practice which has been criticized by authors who have little sympathy for the lex loci rule. ${ }^{133}$ This "overworked epithet" ${ }^{134}$ can of course apply to any connecting factor, including domicile, ${ }^{135}$ and to any given configuration of connecting factors.

A more serious argument against the rule is the impossibility of localizing intangible injuries, ${ }^{136}$ such as loss of good will and impairment of reputation. In the case of torts such as fraud, defamation, unfair competition, and invasion of privacy, the wrongful act is not directed against an object having a physical location, and thus there is no "place of injury." This consideration, however, would not justify wholesale abolition of the rule; it merely suggests the need for more appropriate contacts in situations in which use of this connecting factor makes no sense. ${ }^{137}$

The rule has also been criticized as simplistic, but its retention does not preclude certain refinements. Rather than using the law of the place of the injury like a blunderbuss to govern all issues, selection of another law might be proper for certain issues, ${ }^{138}$ such as charitable immunity, ${ }^{139}$ releases, ${ }^{140}$ and intrafamily liability. ${ }^{\mathbf{1 4 1}}$

Even if one believes in governmental interests and the need to accommodate them, the lex loci rule might have appeal as the most practical accommodation of these interests. The law of each state would get its turn, and at the same time the problems that now vex the courts

132 See, e.g., Watts v. Pioneer Corn Co., 342 F.2d 617 (7th Cir. 1965) ; Duffy v. Currier, 291 F. Supp. 810 (D. Minn 1968) ; Fabricius v. Horgen, 257 Iowa 268, 132 N.W.2d 410 (1965); Wessling v. Paris, 417 S.W.2d 259 (Ky. 1967); Kilberg v. Northeast Airlines, Inc., 9 N.Y.2d 34, 172 N.E.2d 526, 211 N.Y.S.2d 133 (1961); Woodward v. Stewart, - R.I. -, 243 A.2d 917 (1968), petition for cert. dismissed, 393 U.S. 957 (1969).

133 See Cavers 311-12; Trautman, supra note 89 , at 465-66.

134 CAVERS 311-12.

135 See id. In view of the increasing mobility of people, the concept of domicile is losing reality and significance. See LEFLAR 15-16. Compare RestateMENT of Conflict of Laws $\$ 9$ (1934), with Restatenent (Second) of Conflict of Laws $\$ 11$ (Proposed Official Draft, part I, May 2, 1967). See also, e.g., Hopkins v. Lockheed Aircraft Corp., 201 So. $2 \mathrm{~d} 749,752$, rew'g on rehearing, 201 So. $2 \mathrm{~d} 743$ (Fla. 1967).

136 See generally LEFLAR 333-40.

137 For possible approaches see Restatenient (Second) of Conflict of Laws $\S \S 148-55$ (Proposed Official Draft, part II, May 1, 1968).

138 ReSTATEMENT (SECOND) favors a differentiated approach. See the groupings of "Particular Torts" in chapter 7, topic 1, title B ( $\$ 146-55$ ), and of "Particular Issues" in title C ( $\$$ 156-74) (Proposed Official Draft, part II, May 1, 1968).

138 See Blum v. American Youth Hostels, Inc., 40 Misc. 2d 1056, 244 N.Y.S.2d 351 (Sup. Ct. 1963), aff'd on other gronnds, 21 App. Div. 2d 683, 250 N.Y.S.2d 522 (1964). But see Kaufman v. American Youth Hostels, Inc., 5 N.Y.2d 1016, 158 N.E.2d 128, 185 N.Y.S.2d 268 (1959). See generally Cavers 19-58.

140 See Manos v. Trans World Airlines Inc., 295 F. Supp. 1166 (N.D. IIl. 1968) ; Daily v. Somberg, 28 N.J. 372, 146 A.2d 676 (1958); Root v. Kaufman, 48 Misc. 2d 468, 265 N.Y.S.2d 201 (Civ. Ct. 1965).

141 See Roscoe v. Roscoe, 379 F.2d 94 (D.C. Cir. 1967) ; Emery v. Emery, 45 Cal. 2d 421, 289 P.2d 218 (1955); Balts v. Balts, 273 Minn. 419, 142 N.W.2d 66 (1966). 
could be avoided in the common interest of all. While the selection of the place of injury may be arbitrary, any other connecting factor might prove equally arbitrary. It is not unheard of to apply a mechanical solution to the allocation of jurisdiction among sovereigns. Witness, for example, the rules on penal jurisdiction in ship collisions. ${ }^{142}$ The very fact that the lex loci rule is simple and mechanical would produce decisions untainted by provincial bias and eliminate manipulation. Indeed, its impartiality evokes the very image of blindfolded justice.

Yet, the dispassionate neutrality of lex loci may be a vice rather than a virtue. Cavers said a generation ago that "the fabric of this blindfold is a legal theory." 143 Judges do not exclude from consideration the consequences that follow from application of competing rules. Their predilection for desirable results led them, before the current wave of outright abolition, to evade the consequences of the lex loci rule by devious means. The resort to "cover up devices" has been sufficiently documented and requires no further comment. ${ }^{144}$ The vice of lex loci is that its guaranty of neutrality implies a disclaimer of quality in the results following from its application.

\section{B. Teleological Approaches}

Why are the results produced by such an innocuous rule so unsatisfactory that courts have felt compelled either to evade or abolish it? The categories of cases that induced courts to adopt new rationales suggest an answer. These decisions primarily involved guest statutes, ${ }^{145}$ intrafamily immunity, ${ }^{146}$ wrongful death limitations, ${ }^{147}$ and the survival of actions. ${ }^{148}$ The perusal of a standard treatise on the law of torts indicates the extent to which the law on these points is replete with relics

142 See Convention on the High Seas, March 24, 1961, [1962] art. 11(1), 13 U.S.T. 2316, T.I.A.S. No. 5200. This treaty provides that penal proceedings can be instituted only by authorities of the flag state or the state of which defendant is a national.

143 Cavers, $A$ Critique of the Choice-of-Law Problem, 47 Harv. L. Rev. 173, 180 (1933).

144 See generally LEFLAR 212-17, 257-58, 323-24.

145 See, e.g., Clark v. Clark, 107 N.H. 351, 222 A.2d 205 (1966); Babcock v. Jackson, 12 N.Y.2d 473, 191 N.E.2d 279, 240 N.Y.S.2d 743 (1963).

146 See, e.g., Balts v. Balts, 273 Minn. 419, 142 N.W.2d 66 (1966); Johnson v. Johnson, 107 N.H. 30, 216 A.2d 781 (1966).

147 See, e.g., Reich v. Purcell, 67 Cal. 2d 551, 432 P.2d 727, 63 Cal. Rptr. 31 (1967) ; Miller v. Miller, 22 N.Y.2d 12, 237 N.E.2d 877, 290 N.Y.S.2d 734 (1968).

148 See, e.g., Griffith v. United Air Lines, Inc., 416 Pa. 1, 203 A.2d 796 (1964). Other types of cases evince a similar trend to grant recovery to injured plaintiffs. See, e.g., Gaither v. Myers, 404 F.2d 216 (D.C. Cir. 1968) (owner's liability); Swanson v Badger Mut. Ins. Co., 275 F. Supp. 544 (N.D. I1l. 1967) (direct action statute); Mitchell v. Craft, 211 So. 2d 509 (Miss. 1968) (contributory negligence); Farber v. Smolack, 20 N.Y.2d 198, 229 N.E.2d 36, 282 N.Y.S.2d 248 (1967) (owner's liability). 
inspired by outdated philosophies or fostered by lobbyist pressures. ${ }^{149}$ These "drag[s] on the coattails of civilization" 150 promote no useful social purpose. Opinions that have attempted to articulate the policies behind such rules by applying modern methods of analysis have illustrated their flimsiness. ${ }^{151}$ It is no wonder that courts are inclined to shun them. Applied without corrective, the lex loci rule will inevitably produce hardships, not because it is a bad rule, but because it invokes bad law. To cure the problem at its roots would require an overhaul of the substantive law. But widespread law reform is only a faint hope, and in the meantime judges must dispose of cases. The "looseness in the joints of the apparatus" ${ }^{152}$ of conflicts law may well induce a court to use it in such a manner as to avoid invidious results.

149 See W. Prosser, Handoook of the LAW of Torts 190-91 (guest statutes), 428 (contributory negligence), 879 (intrafamily immunity), 923-37 (wrongful death) (3d ed. 1964).

150 Cheatham \& Reese, Choice of the Applicable Law, 52 Colum. L. REv. 959, 978-80 (1952).

151

The only reasons that have ever been given ... for enactment of its [Vermont's] guest statute are (1) to protect kindly hosts from ungrateful guests ("don't bite the hand that feeds you"), and (2) to protect liability insurance companies from suits brought by guests colluding with their hosts. ... .

The automobile guest statutes were enacted in about half the states, in the 1920's and early 1930's, as a result of vigorous pressures by skillful proponents. Legislative persuasion was largely in terms of guest relationships (hitchhikers) and uninsured personal liabilities that are no longer characteristic of our automotive society. . . The problems of automotive accident law then were not what they are today. . . . No American state has newly adopted a guest statute for many years. Courts of states which did adopt them are today construing them much more narrowly, evidencing their dissatisfaction with them. . . Though still on the books, they contradict the spirit of the times.

Clark v. Clark, 107 N.H. 351, 356-57, 222 A.2d 205, 209-10 (1966).

Without discoursing at great length, it can be said that wrongful death limitations serve little purpose. So strong has been the reaction to such limitations that some courts have upheld the application of the wrongful death law of non-forum states but have at the same time disallowed the limitation of those laws on public policy grounds. See Kilberg v. Northeast Airlines, 9 N.Y.2d 34, [172 N.E.2d 526, 211 N.Y.S.2d 133 (1961)] ; Pearson v. Northeast Airlines, 309 F.2d 553 (2d Cir. 1962).

Tiernan v. Westext Transport, Inc., 295 F. Supp. 1256, 1264 (D.R.I. 1969)..

We are of the opinion that experience has demonstrated no necessity for continuing the doctrine of immunity as a defense in tort actions brought by a parent against a child. Our conclusion is influenced by the increasing frequency and severity of automobile accidents and the seriousness of attendant injuries to members of the same household. The fact that in most instances the driver is covered by liability insurance minimizes the likelihood of intrafamily discord. While, of course, our decision will also affect the uninsured and will reach into family activities beyond the operation of an automobile, the prospect of vexatious or collusive litigation we believe has no substantial basis. Only where a serious wrong has been committed is it likely that children's torts will be brought to the attention of the courts. Otherwise, we are persuaded that the good judgment, restraint, and discernment of parents, lawyers, judges, and juries will act as an effective deterrent to the prosecution of fraudulent or frivolous litigation.

Balts v. Balts, 273 Minn. 419, 433, 142 N.W.2d 66, 75 (1956).

152 B. Currie, Selected Essays on the Conflict of Laws 105 (1963) [here-

inafter cited as CuRRIE]. 
This phenomenon is not a new one. It appeared as soon as courts felt free to apply a law other than that of the forum. ${ }^{153}$ Result selectivity ${ }^{154}$ has found expression in the classification of statutes as "odious," ${ }^{155}$ in the public policy reservation, ${ }^{156}$ and in the astute use of such "escape devices" 157 as renvoi and characterization. Not all of the moderns are entirely adverse to it; witness such notions as "emerging" and "regressive" rules, ${ }^{158}$ and the mention of justice in the individual case ${ }^{159}$ or the better rule of law ${ }^{160}$ in lists enumerating choice of law desiderata. At present, ${ }^{161}$ the most outspoken advocate of a teleological approach is Leflar, who, in his discussion of choice-influencing considerations, vigorously defends the propriety of applying the better rule of law. ${ }^{102}$

\section{Modern Methodologies}

Opinions in cases that have adopted modern theories have explicitly referred to "justice, fairness, and the best practical result" as a justification for modern analysis. ${ }^{163}$ In fact, most of the cases in which courts abandoned the lex loci rule involved avoidance of noxious substantive law. ${ }^{164}$ However, the precedent of decisions in which the

153 See the gloss ascribed to Aldricus set forth and discussed in Yntema, The Comity Doctrine, 65 MICE. L. REv. 9, 12 (1966).

154 See LEFLAR 217.

155 See references in EHRENzWEIG, P.I.L. 97, 153.

156 Id. 153-68.

157 LEFLAR 217.

158 A. von Mehren \& D. Trautman, The Law of Multistate Problems 377, 394, 407-08 (1965).

159 Cheatham \& Reese, Choice of the Applicable Law, 52 CoLUm. L. Rev. 959, 980-81 (1952).

160 LEFLAR 254.

161 For earlier statements favoring teleology see Freund, Chief Justice Stone and the Conflict of Laws, 59 HARv. L. REv. 1210, 1214 (1946) ; Lorenzen, Territoriality, Public Policy and the Conflict of Lazes, 33 Y YLE L.J. 736 (1924); Yntema, supra note 153. See Siegelman v. Cunard White Star, Ltd., 221 F.2d 189, 206 (2d Cir. 1955) (Frank, J., dissenting).

162 Leflar 216-18, 254-59. See also D. Currie, in Comments on Reich v. Purcell, 15 U.C.L.A.L. Rev. 595 (1968); Ehrenzweig, in id. 570; Horowitz, in id. 631, 636; Leflar, in id. 637, 640; Scoles, in id. 563.

163 Babcock v. Jackson, 12 N.Y.2d 473, 481, 191 N.E.2d 279, 283, 240 N.Y.S.2d 743, 749 (1963) ; see Watts v. Pioneer Corn Co., 342 F.2d 617, 618 (7th Cir. 1965) (lex loci delicti "[fails] to cope with the complexities of modern day multistate occurrences"); Manos V. Trans World Airlines, Inc., 295 F. Supp. 1170, 1173 (N.D. Ill. 1968) ("lex loci delicti rule . . . worked injustices").

164 Williams v. Rawlings Truck Line, Inc., 357 F.2d 581 (D.C. Cir. 1965) (owner's liability); Merchant's Nat'l Bank \& Trust Co. v. United States, 272 F. Supp. 409 (D.N.D. 1967) (wrongful death limitation); Schwartz v. Schwartz, 103 A riz. 562, 447 P.2d 254 (1968) (intrafamily immunity); Reich v. Purcell, 67 Cal. 2d 551, 432 P.2d 727, 63 Cal. Rptr. 31 (1967) (wrongful death limitation); Wessling v. Paris, 417 S.W.2d 259 (Ky. 1967) (guest statute); Schneider v. Nichols, 280 Minn. 139, 158 
courts avoided an undesirable rule by abandoning lex loci often has compelled the same courts in later cases to apply a law which was equally undesirable. ${ }^{165}$ Moreover, preoccupation with analysis in terms of interests and policies may have served to inhibit, rather than to promote, discussion of the much more fundamental question: whether it is proper to use the law of conflicts for the avowed purpose of result selectivity. ${ }^{166}$ A methodology that is oriented towards the competing claims of interested states can provide the flexibility necessary to enable courts to reach just results. ${ }^{167}$ But once the highest court decides a case, the holding is law, even though the court applied modern methodology in reaching its decision. It may be inordinately difficult later to avoid the logic of an earlier opinion. ${ }^{168}$ Having decided Babcock, the New York Court of Appeals could not have reached the same result as the Third Judicial Department in Kell $v$. Henderson, unless it abolished the rule of stare decisis. Consistency would have required the judges to repress

N.W.2d 254 (1968) (guest statute) ; Mitchell v. Craft, 211 So. 2d 509 (Miss. 1968) (contributory negligence); Clark v. Clark, 107 N.H. 351, 222 A.2d 205 (1966) (guest statute); Mellk v. Sarahson, 49 N.J. 226, 229 A.2d 625 (1967) (guest statute); Babcock v. Jackson, 12 N.Y.2d 473, 191 N.E.2d 279, 240 N.Y.S.2d 743 (1963) (guest statute); Griffith v. United Air Lines, Inc., 416 Pa. 1, 203 A.2d 796 (1964) (survival of action); Woodward v. Stewart, 243 A. 2d 917 (R.I. 1968), petition for cert. dismissed, 393 U.S. 957 (1969) (guest statute). But see Casey v. Manson Constr. \& Eng'r Co., 247 Ore. 274, 428 P.2d 898 (1967). After a thorough discussion, the Oregon Supreme Court adopted the Restatement (Second) test to deny a wife domiciled in Oregon recovery for loss of consortium by applying Washington law on the grounds that. Washington, the place of injury, had the more significant relationship. Other cases in which courts abandoned lex loci but failed to avoid application of a distasteful rule include Watts v. Pioneer Corn Co., 342 F.2d 617 (7th Cir. 1965) (wrongful death limitation); Wartell v. Formusa, 34 Ill. 2d 57, 213 N.E.2d 544 (1966) (intrafamily immunity); Fabricius v. Horgen, 257 Iowa 268, 132 N.W.2d 410 (1965) (wrongful death limitation).

165 See Fuerste v. Bemis, 156 N.W.2d 831 (Iowa 1968) (guest statute); Johnson v. Johnson, 107 N.H. 30, 216 A.2d 781 (1966) (intrafamily immunity); Dym v. Gordon, 16 N.Y.2d 120, 209 N.E.2d 792, 262 N.Y.S.2d 463 (1965) (guest statute) ; cf. Ciprari v. Servicos Aereos Cruzeiro do sul, S. A. (Cruzeiro), 359 F.2d 855 (2d Cir. 1966) (wrongful death limitation); Satchwill v. Vollrath Co., 293 F. Supp. 533 (E.D. Wis. 1968) (wrongful death limitation); Shaver v. Soo Line R.R., 284 F. Supp. 701 (E.D. Wis. 1968) (wrongful death right of action); Cashman v. Evans, 249 F. Supp. 273 (S.D.N.Y. 1966) (guest statute).

166 For a discussion of the problematic nature of the result selectivity approach see Baxter, Choice of Law and the Federal System, 16 StAN. L. REv. 1, 5-6 (1963). 167

[O]ne cannot easily suppress the suspicion, or should we say the hope, that it was . . . a "better-rule" motivation, rather than the invoked nonrule of the "most significant relationship," ... that led the New York Court of Appeals so to interpret the forum rule spatially as to permit in one case "a substantial recovery" for a crash death under Pennsylvania law (rather than limited damages under Maryland law); and in another case, a direct action against a liability insurer under Puerto Rico law (against a "procedural" forum rule to the contrary).

ERrenzweig, P.I.L. 100 (footnotes omitted).

168 See cases cited note 165 supra. In Rosenberg, An Opinion for the New York Court of Appeals, in Two Views on Kell v. Henderson, 67 Colum. L. REv. 459, 464 (1967), the author likens the effort of throwing away a choice of law rule to that of throwing away a boomerang, in view of stare decisis. 
their sympathies for the injured party and to deny recovery, in a case in which the lex loci rule would have made the victim whole.

It can of course be argued that a party may not complain if the law of his home state is applied, whatever the content of such law may be. But if the unfairness is rooted in an unjust substantive rule, this argument has little cogency. Applying the Massachusetts ceiling on wrongful death recovery to a case which has no foreign contacts whatever is equally as unfair as applying it to an interstate situation. The only difference is that no other rule is conceivably available. Yet in no real sense is a Massachusetts citizen accountable for such pernicious law. ${ }^{169}$ Subjecting domiciliaries of a state to its draconic rules is less, but only somewhat less, perverse than the extension of such precepts to strangers. Kell illustrates that judges may not be satisfied that application of the party's "home law" is necessarily fair, even though all relevant contacts other than the "fortuitous" place of accident point to that law.

Although sophisticated courts may be flexible enough to avoid the consequences of earlier pronouncements, as exemplified by the decision of the New York Court of Appeals in Miller v. Miller, ${ }^{170}$ others will be less inclined to stretch precedent to avoid application of an onerous law, and some may go so far as to adopt new methodologies to reach regrettable results. ${ }^{171}$ Flexible approaches are less unsatisfactory than rigid rules only to the extent they are manipulated with agility. Manipulation, however, is contrary to the spirit in which these approaches were conceived. ${ }^{172}$ Currie denied that it could or should be the function of courts to favor the better law, because in his opinion they lack both the freedom and the competence to do so. ${ }^{173}$ Cavers was said to have advocated justice in the individual case, ${ }^{174}$ but if he ever did, ${ }^{175}$ he has since re-

169 See D. CURRIE, supra note 162, at 599; Wright, The Federal Courts and the Nature and Quality of State Laze, 13 WAYNE L. REv. 317, 328 (1967).

17022 N.Y.2d 12, 237 N.E.2d 877, 290 N.Y.S.2d 734 (1968).

171 See Watts v. Pioneer Corn Co., 342 F.2d 617 (7th Cir. 1965); Wartell v. Formusa, 34 I1l. 2d 57, 213 N.E.2d 544 (1966) ; Fabricius v. Horgen, 257 Iowa 268 , 132 N.W.2d 410 (1965) ; Casey v. Manson Constr. \& Eng'r Co., 247 Ore. 274, 428 P.2d 898 (1967).

172 But see Hancock, The Rise and Fall of Buckeye v. Buckeye, 1931-1959: Marital Immminty for Torts in Conflict of Laws, 29 U. CHI. L. REv. 237, 252-58 (1962) ; Horowitz, in Comments on Reich v. Purcell, 15 U.C.L.A.L. REV. 631, 636 (1968); Scoles, in id., 563, 567-69; Weintraub, in id., 556; Weintraub, $A$ Method for Solving Conflicts Problems-Torts, 48 Cornent L.Q. 215, 238, 249 (1962). Baade says that governmental interest analysis is one application of teleological interpretation. Baade, Counter-revolution or Alliance for Progress? Reflections on Reading Cavers, The Choice-of-Lawe Process, 46 Texas L. Rev. 141, 149 (1967). But see id., 154-56.

173 E.g., CuRRIE 104-06, 133, 153-54.

174 See, e.g., Kenison, C.J., in Clark v. Clark, 107 N.H. 351, 357, 222 A.2d 205, 210 (1966); Cheatham \& Reese, supra note 159, at 959, 980-81; CURRIE 159 n.82.

175 See Cavers, A Critique of the Choice-of-Law Problem, 47 HARv. L. Rev. 173, 193 (1933). 
canted. ${ }^{178}$ Reese listed justice as one of the policy factors of conflicts, ${ }^{177}$ but, as Reporter for the Second Restatement, substantially reduced its significance. ${ }^{178}$

But it is of course incongruous to direct judges to inquire into the content and policies of potentially applicable substantive law, and to admonish them, at the same time, to refrain from a selection motivated by their desire to do justice. In his early article, Cavers asserted that "only a judge in whom the legal mind . . . has hypertrophied could exclude from consideration the consequences of the application of the proffered law to the facts of the given case." ${ }^{179}$ A judge freed from the blindfolds with which lex loci had adorned him and equipped with the telescope of functional analysis should not be expected to be impervious to what he sees. The degree of hypertrophy postulated by such an expectation should be sufficient to disqualify a judge from holding office. ${ }^{180}$

Given the present fluidity of conflicts law, the question whether it is proper and desirable that courts adopt a result-selective approach may already have been answered..$^{181}$ The vacillation and uncertainty, in theory ${ }^{182}$ as well as in practice, ${ }^{183}$ in the jurisdictions which have joined the conflicts revolution would strongly suggest a return to the lex loci

176 CAvers 75-87.

177 Cheatham \& Reese, supra note 159, at 980.

178 According to Restatenent (SeCOND) of Conflict of Laws $\$ 6(2)$ (d) (Proposed Official Draft, part I, May 2,1967), one of the factors relevant to choice of law is the protection of justified expectations. According to comment $g$, id. 18, there are no expectations to protect whenever parties act without giving thought to the legal consequences of their conduct, particularly in the area of negligence.

179 Cavers, supra note 175 , at 181 .

180 Given his decisions in Grant v. McAuliffe, 41 Cal. 2d 859, 264 P.2d 944 (1953), Emery v. Emery, 45 Cal. 2d 421, 289 P.2d 218 (1955), and Bernkrant v. Fowler, 55 Cal. 2d 588, 360 P.2d 906, 12 Cal. Rptr. 266 (1961), which do seem to evince a very definite spirit of enlightenment on the part of Judge Traynor, as well as a talent for deft manipulation, one feels tempted to ask whether the judge would feel constrained by the logic of his decision in Reich v. Purcell, 67 Cal. $2 \mathrm{~d}$ 551, 432 P.2d 727, 63 Cal. Rptr. 31 (1967), to decide the cases posited by Cavers, in Comments on Reich v. Purcell, 15 U.C.L.A.L. REv. 647, 648, 652 (1968), in the manner suggested by Cavers. Some comments on the case seem to express concern that the judge may find himself hoisted by his own petard. See Scoles, in id. 569; Weintraub, in id. 561-63. But the judge's opinion would seem to leave some leeway for the disposition of future cases in a result-selective fashion, if only by seizing upon the words "interests of litigants," 67 Cal. $2 \mathrm{~d}$ at 553, 432 P.2d at 729, 63 Cal. Rptr. at 33, which he used in conjunction with the interests of states he analyzed.

181 See notes 153-62 supra \& accompanying text. Apart from the result selectivity inherent in the modern theories, the opportunities offered by long-arm legislation work in plaintiff's favor. See note 187 infra \& accompanying text.

182 See D. Currie, in Comments on Reich v. Purcell, 15 U.C.I.A.I. REv. 595, 595-97 (1968).

183 Compare Babcock v. Jackson, 12 N.Y.2d 473, 191 N.E.2d 279, 240 N.Y.S.2d 743 (1963), and Macey v. Rozbicki, 18 N.Y.2d 289, 221 N.E.2d 380, 274 N.Y.S.2d 591 (1966), with Dym v. Gordon, 16 N.Y.2d 120, 209 N.E.2d 792, 262 N.Y.S.2d 463 (1966), and Cashman v. Evans, 249 F. Supp. 273 (S.D.N.Y. 1966). 
or some other stable ${ }^{184}$ rule. Only if the justice of the end result is considered to be a desideratum of a higher order than impartiality should neutral choice of law rules be discarded. It may be singularly inappropriate to burden conflicts law with the responsibility for results, but it is certainly not impossible. There are several forms that a teleological approach can take.

\section{Alternative Reference Rules}

As noted earlier, ${ }^{185}$ the real difficulty in many cases lies not with conflicts theory, but with substantive tort law, and in particular with rules which arbitrarily inhibit or diminish recovery. An alternative reference rule is a simple expedient to resolve the problem. Such a rule would entitle the victim to the most favorable of the potentially applicable rules.

There is nothing new or unusual about such a solution. Lorenzen noted, with apparent approval, that the former German Supreme Court "interpreted" its lex loci rule in such a manner that the law which is most favorable to the injured party is always applied. ${ }^{186}$ Ehrenzweig's forum preference is partly motivated by the consideration that, in view of modern long-arm legislation, the lex fori rule "will usually result in the plaintiff's option to choose the law most favorable to him." ${ }^{187}$ It has been said that a similar idea underlies Cavers's Principles of Preference; ${ }^{188}$ and the Second Restatement explicitly recognizes alternative reference rules in the areas of usury ${ }^{189}$ and trusts. ${ }^{190}$

Thus, in several instances, conflicts rules have been charged with the specific task of furnishing proper results from diffuse and disparate substantive laws. It is true that the justification advanced in the Restatement for alternative reference rules in trusts and usury may not apply to torts, where disparities are not limited to percentage points ${ }^{191}$

184 In abandoning the lex loci rule, the Kentucky Court of Appeals said:

We recognize that an attempt to apply this rule [the Restatement test] in complex situations might involve an unstable exercise in legal gymnastics. Consequently, at this time we limit the application of this rule to a very clear

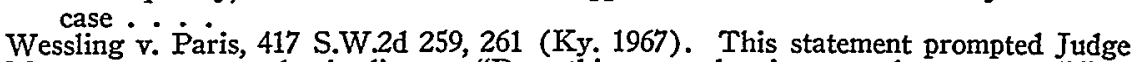
Montgomery to wonder in dissent: "Does this mean that in an unclear case a different rule will obtain?" Id.

185 See text accompanying notes $145-51$ supra.

186 Lorenzen, Tort Liability and the Conflict of Lazes, 47 L.Q. REv. 483, 491-94

(1931); see EHRENZWEIG, TREATISE 555 n.31, 597.

187 EHRENZWEIG, TrEatise 555.

188 E.g., Baade, supra note 172, at 162-63.

180 Restatement (SECONd) of Conflict of Laws $\$ 203(2)$ (Proposed Official Draft, part II, May 1, 1968).

190 Restatement (SECOND) OF CONFict of Laws $\$ 269$ (b) (ii) (Proposed Official Draft, part III, April 22, 1969).

$191 \mathrm{See}$ Restatement (SECOND) OF CONFLiCT of LaWs $\$ 203$, comment $b$ at 294-95 (Proposed Official Draft, part II, May 1, 1968). 
and life spans, ${ }^{192}$ but indemnification of tort victims is surely of no lesser importance than the "expectations of the parties" to a usurious contract. ${ }^{193}$ As a general proposition, it would not seem unreasonble to let the onus of conflicting laws be borne by the tortfeasor rather than by his victim. ${ }^{194}$

\section{Public Policy}

A blunter tool that might be used for purposes of result-selectivity is the notion of public policy. ${ }^{195}$ One difficulty with this doctrine is, however, that nonapplication of foreign law which violates forum policy might leave the plaintiff without any remedy. ${ }^{196}$ Although with some ingenuity this result can be avoided, as Judge Desmond's opinion in Kilberg v. Northeast Airlines, Inc. ${ }^{197}$ indicates, public policy, unlike an alternative reference rule, does not afford the possibility of avoiding undesirable forum law. Moreover, the propensity of the doctrine to interfere with, rather than to foster, conflicts analysis, has been noted, ${ }^{198}$ and persuasive arguments have been advanced against the propriety of applying it to interstate (as opposed to international) conflicts cases. ${ }^{199}$

102 See Restatement (Second) of Conflict of Laws \$269, comment $i$ at 199 (Proposed Official Draft, part III, April 22, 1969).

193 Validation of usurious contracts by means of an alternative reference rule has not escaped cogent criticism. See A. EHRENZWEIG, CONFLICT OF LAWS 485 (1962) [hereinafter cited as EHRENZwEIG, TREATISE]; Note, Usury in the Conflict of Laws: The Doctrine of the Lex Debitoris, 55 CALIF. L. REv. 123, 148-80 (1967).

184

In torts, the plaintiff has no opportunity to bargain about the relationship between the parties. He is the innocent victim who suffers by an event fortuitous as regards his participation. As compared to the plaintiff, the defendant has less fortuitous participation by reason of his negligence.

Scoles, in Comments on Reich v. Purcell, 15 U.C.L.A.L. Rev. 563, 569 (1968).

195 The concept has been strongly attacked by Paulsen \& Sovern, "Public Policy" it the Conflict of Lazes, 56 ColvM. L. REv. 969 (1956); cf. D. CAVERS, THE CHOICE of Law Process 201 (1965) [hereinafter cited as Cavers]. Contra, A. Ehrenzweig, PrTVATE International LaW 156 (1967) [hereinafter cited as EHRENzWEIg, P.I.L.].

196 Home Ins. Co. v. Dick, 281 U.S. 397 (1930); see Restatement (Second) of CoNFLICT OF LAWS $\$ 90$ \& comment $a$ at 330-31 (Proposed Official Draft, part I, May 2, 1967). But see Bernstein v. Van Heyghen Freres Societe Anonyme, 163 F.2d 246 (2d Cir.), cert. denied, 332 U.S. 772 (1947).

1979 N.Y.2d 34, 172 N.E.2d 526, 211 N.Y.S.2d 133 (1961). Characterization of a rule as "procedural" can of course produce the same result. In Kilberg, Judge Desmond used this technique to bolster his other line of reasoning. Id. at 41,172 N.E.2d at 529, 211 N.Y.S.2d at 137 . The classical case for result-selective application of the term "procedural" is Grant v. McAuliffe, 41 Cal. 2d 859, 264 P.2d 944 (1953) (applying California survival statute to Arizona accident in the aegis of the lex loci rule). See Traynor, Is This Conflict Really Necessary?, 37 TEx. L. REv. 657, 670 n.35 (1959).

198 Paulsen \& Sovern, supra note 195, at 1016.

199 Id. 1012-16; Griswold, quoted in CAvers 22; Restatement (Second) of Conflict of Laws $\$ 90$, comment $c$ at $331-32$ (Proposed Official Draft, part I, May 2, 1967). 


\section{The Better Rule}

The most explicit recognition of the result-selective approach is the selection of the substantive rule which, in the opinion of the court, is the best law. Arguably, at least two states have already adopted this approach for tort choice of law. In Clark v. Clark ${ }^{200}$ and Conklin v. Horner ${ }^{201}$ the supreme courts of New Hampshire and Wisconsin applied forum law to compensate automobile passengers; in the process they rejected potentially applicable sister state guest statutes that might have barred recovery. In modern parlance, the New Hampshire case was an "easy" one, the Wisconsin case "difficult." 202 In Clark, application of any of the various modern methods could have yielded the same result since all relevant factors except the "fortuitous" place of accident pointed to New Hampshire. In Conklin, the law-fact pattern was exactly the reverse. In other words, the two cases presented the New Hampshire and Wisconsin courts with the very problems that Babcock and Kell posed in New York. Both of the latter cases relied on Leflar's choiceinfluencing considerations, ${ }^{203}$ but they deemphasized in varying degrees the importance of other considerations in favor of the last item on Leflar's list-that is, application of the better rule of law. Addressing himself to this consideration, Judge Kenison, speaking for the Supreme Court of New Hampshire, said:

We prefer to apply the better rule of law in conflicts cases just as is done in nonconflicts cases, when the choice is open to us. If the law . . . is outmoded, an unrepealed remnant of a bygone age, "a drag on the coattails of civilization," . . . we will try to see our way clear to apply our own law instead. If it is our own law that is obsolete or senseless (and it could be) we will try to apply the other state's law. Courts have always done this in conflicts cases, but have usually covered up what they have done by employing manipulative techniques . . . . 204

The same emphasis on result-selectivity reasoning appears from Judge Heffernan's opinion in the Conklin case. ${ }^{205}$ If result-selectivity is the decisive factor, Conklin is consistent with Clark.

It is interesting to compare the treatment of governmental interests in the two cases. Stating that it was his duty to further New Hamp-

200107 N.H. 351, 222, A.2d 205 (1966). See Baade, supra note 172, at 152-55 for a discussion of this case as a "better rule" decision.

20138 Wis. $2 \mathrm{~d} 468,157$ N.W.2d 579 (1968).

202 Cf. Trautman, $A$ Comment, in Two Viezes on Kell v. Henderson, 67 CoLum. L. REv. 465,468 (1967).

203 See note 87 supra \& accompanying text.

204107 N.H. at 355,222 A.2d at 209.

20538 Wis. $2 \mathrm{~d}$ at $484-85,157$ N.W.2d at 587 . It is clear from his citation of Kell v. Henderson, 47 Misc. $2 \mathrm{~d} 992,263$ N.Y.S.2d 647 (1965), and of Rosenberg, An Opinion for the New York Court of Appeals, in Two Views on Kell v. Henderson, 67 CouvM. L. REv. 459 (1967), that Judge Heffernan knew exactly what he was doing. Id. at $485-86$ n.12, 157 N.W. 2 d at $587-88$ n.11. 
shire's governmental interests in favor of New Hampshire residents, Judge Kenison interpreted Vermont's interests as only relating to actions brought in Vermont courts and affecting Vermont parties. ${ }^{206}$ Yet earlier in his opinion he asserted that in "most private litigation the only real governmental interest that the forum has is in the fair and efficient administration of justice." ${ }^{207}$ After finding that Wisconsin had a serious concern over accidents occurring on its highways, Judge Heffernan determined that a true conflict therefore existed, ${ }^{208}$ but thought it unlikely "that Illinois governmental interests are so concerned that retaliatory conduct would ensue." 209 He also quoted a passage from another recent Wisconsin case, Zelinger $v$. State Sand \& Gravel Company, ${ }^{210}$ which indicated that the court "would apply the law of a non-forum state if it were the better law." 211

The language in these cases, their peculiar treatment of governmental interests, the manner in which they disposed of earlier decisions, ${ }^{212}$ and the dissent in Conklin ${ }^{213}$ all suggest that both courts opted

206107 N.H. at 356,222 A.2d at 209-10.

207 Id. at 355, 222 A.2d at 208-09.

20838 Wis. 2 d at 475,157 N.W.2d at 582.

200 Id. at 479,157 N.W.2d at 584.

21038 Wis. $2 d$ 98, 156 N.W.2d 466 (1968).

21138 Wis. 2d at 484,157 N.W.2d at 587 (quoting Zelinger v. State Sand \& Gravel Co., 38 Wis. 98, 113,156 N.W.2d 466, 473 (1968)). Along the same lines, see the quote from Judge Kenison's opinion in Clark $v$. Clark in text accompanying note 204 sipra.

212 The development of the law in Wisconsin neatly demonstrates the evolutionary process that preceded, and must have influenced, the court's determination in Conklin v. Horner, 38 Wis. 2d 468, 157 N.W.2d 579 (1968). Wisconsin began with the lex fori rule, Anderson v. Milwaukee \& St. P. R.R., 37 Wis. 321 (1875), and shifted to loci delicti in Bain v. Northern Pac. R.R., 120 Wis. 412, 98 N.W. 241 (1904). In Haumschild v. Continental Cas. Co., 7 Wis. 2d 130, 95 N.W.2d 814 (1959), the court evaded the undesirable result which would have followed from an application of the lex loci delicti rule by characterizing the question of interspousal immunity as one of family law, not of tort law. See Hancock, The Rise and Fall of Buckeye v. Buckeye, 1931-1959: Marital Immunity For Torts in Conflict of Lazes, 29 U. CHI. L. Rev. 237 (1962). The Wisconsin Supreme Court abandoned lex loci delicti in Wilcox v. Wilcox, 26 Wis. 2d 617, 133 N.W.2d 408 (1965), applying the law of the state with the most significant relationship. In the Wilcox opinion, Judge Heffernan spoke of a flexible approach which would lead to just results, and suggested an alternative reference rule. In Heath v. Zellmer, 35 Wis. 2d 578, 151 N.W.2d 664 (1967), the court adopted an approach based on the relative interests of the states involved. It switched to Ieflar's choice-influencing considerations in Zelinger v. State Sand \& Gravel Co., 38 Wis. 2d 98, 156 N.W.2d 466 (1968). Shortly thereafter, the same court decided Conklin v. Horner, 38 Wis. 2d 468, 157 N.W.2d 579 (1968) in which it emphasized the better law rule. The significance of the fact that Conklin is the culmination of a development that has run the full gamut of all the theories before arriving at the better rule approach has, however, not been grasped by the federal courts. See Turner v. Pfluger, 407 F.2d 648 (7th Cir. 1969) ; Satchwill v. Vollrath Co., 293 F. Supp. 533 (E.D. Wis. 1968).

A similar development occurred in New Hampshire. See Gray v. Gray, 87 N.H. 82, 174 A. 508 (1934); Thompson v. Thompson, 105 N.H. 86, 193 A.2d 439 (1963); Johnson v. Johnson, 107 N.H. 30, 216 A.2d 781 (1966); Dow v. Larrabee, 107 N.H. 70, 217 A.2d 506 (1966); Clark v. Clark, 107 N.H. 351, 222 A.2d 205 (1966).

213 Judge Hallows, the author of the majority opinion in Zelinger v. State Sand \& Gravel Co., 38 Wis. 2d 98, 156 N.W.2d 466 (1968), in which the court adopted 
for a "better law" rule. ${ }^{214}$ At least, they pose the question of the propriety, desirability, and workability of selecting competing rules on the basis of their intrinsic merits. ${ }^{215}$

One advantage of the better law rule over lex loci is that it can be applied to torts involving injury to intangible interests. ${ }^{210}$ Unlike alternative reference rules, it could weed out inequities that may unduly favor plaintiffs, such as provisions for punitive damages, in addition to compensating injured parties. In contrast to the rigid adherence to the lex fori, general acceptance of this approach would not encourage the unseemly spectacle of forum shopping, if the courts are serious about their stated intention to apply a better foreign rule. ${ }^{217}$ This would work in favor of less resourceful plaintiffs and would prevent powerful defendants from gaining an unfair advantage by selecting a suitable jurisdiction in which to bring a declaratory judgment action. ${ }^{218}$

Another advantage of the "better law" rule is that it does not involve the hazards of uncertainty and lack of predictability inherent in current methodology. A court adopting it would not purport to administer justice ad hoc, ${ }^{219}$ but would have to state the reasons why one tort rule is preferable to another. It is true that reasonable men can

Leflar's choice-influencing considerations, dissented from the better-rule decision in Conklin v. Horner, 38 Wis. 2d 468, 490-91, 157 N.W.2d 579, 590 (1968):

The majority opinion, which like the professors, concludes the law of the forum should be applied is based upon the premise that the host-guest statute is bad law, serves no legitimate purpose, and should be circumvented. The fifth choice-influencing consideration, the better law, then becomes the paramount if not the controlling factor. But in Heath and in Zellinger, we made it clear that none of the choice-influencing considerations standing alone is to be considered controlling.

214 See EHRENzWEIG, P.I.L. 97-98, 100-03; Ehrenzweig, "False Conflicts" and the "Better Rule": Threat and Promise in Multistate Tort Law, 53 U. VA. L. REv. 847 (1967) ; Leflar, Conflict of Laws, 1968 ANN. Survey of Ax. LAw 31, 47 (1969); cf. Baade, supra note 172, at 154-56. But see Satchwill v. Vollrath Co., 293 F. Supp. 533 (E.D. Wis. 1968) (preferring governmental interest and policy of Wisconsin over better rule approach to apply Wisconsin limitation on wrongful death recovery).

215 Minnesota, Mississippi, and Rhode Island have also opted for Leflar's choiceinfuencing considerations. Schneider v. Nichols, 280 Minn. 139, 158 N.W.2d 254 (1968) (nonapplication of sister state guest statute); Mitchell v. Craft, 211 So. $2 \mathrm{~d}$ 509 (Miss. 1968) (application of Mississippi comparative negligence statute); Brown v. Church of Holy Name of Jesus, - R.I. - 252 A.2d 176 (1969) (nonapplication of sister state wrongful death act and charitable immunity); Woodward v. Stewart, 243 A.2d 917 (R.I. 1968), petition for cert. dismissed, 393 U.S. 957 (1968). The Schneider and Woodward cases are fairly explicit in their assertion of superiority of forum over sister state law on point. In Friday v. Smoot, - Del. -, 211 A.2d 594 (1965), the Supreme Court of Delaware retained lex loci and granted recovery, refusing to apply a guest statute. The result in this case, although based on a lex loci rationale, led Baade to characterize it as a "better law" decision. See Baade, supra note 172 , at 146 n. 30 .

216 See text accompanying notes 136-37 supra.

217 See R. Leflar, American Conflicts LAw 256-57 (1968) [hereinafter cited as LEFLAR]; Kramer, Interests and Policy Clashes in Conflict of Laws, 13 RUTGERS L. REv. 523, 560-61 (1959).

218 For a discussion of this possibility see Baade, supra note 172, at 175-78.

219 See LEFLAR 216-18, 254-59, for the difference between the preferred law, which he considers a legitimate consideration, and the unprincipled choice of the "better party." 
differ, but it is difficult to conceive of a bench composed of guest statute enthusiasts, ${ }^{220}$ devotees of limited wrongful death recovery, or intrafamily immunity aficionados. The danger of multiple appeals, split decisions and reversals would be effectively curbed by the stare decisis effect of a decision passing on the soundness of a given torts rule. A change of views would tend to occur only after a major reorientation of tort philosophy. Nor would it be too difficult to determine the jurisdictions whose law is potentially applicable; they can be readily ascertained from Supreme Court cases dealing with such questions as the permissible reach of state workmen's compensation acts. ${ }^{221}$

That this approach parallels the conflicts rule of section 1-105(1) of the Uniform Commercial Code has not escaped judicial attention. ${ }^{222}$ This provision, adopted in almost all states, requires application of the Code on the ground of self-proclaimed superiority ${ }^{223}$ to any transaction that bears "an appropriate" relation to the forum state.

\section{Conchuston}

The acceptance of modern methodology by the courts has posed serious problems for the administration of justice in interstate tort cases. $^{224}$ Courts should cut short their dalliance with theories and methodologies and focus on the narrow, but important, question whether to accept or reject teleology in tort choice of law. Once this question has been answered one way or the other, it will not be too difficult to devise acceptable rules to implement this policy decision.

The propriety of applying choice of law considerations for the avowed purpose of reaching the right result may well be doubted. However, if it is conceded that courts may use the freedom of choice inherent in a conflicts situation in a result-selective manner, the "better law" rule must be considered seriously. In view of the present state of torts choice of law it may be too late to argue that judges lack such freedom. ${ }^{225}$ The

220 Baade, supra note 172 , at 155 .

221 See Crider v. Zurich Ins. Co., 380 U.S. 39 (1965) ; Carroll v. Lanza, 349 U.S. 408 (1955); Cardillo v. Liberty Mut. Ins. Co., 330 U.S. 469 (1947); Pacific Employers Ins. Co. v. Industrial Acc. Comm'n, 306 U.S. 493 (1939); Alaska Packers Ass'n v. Industrial Acc. Comm'n, 294 U.S. 532 (1935).

An unreasonable choice of law may be overturned by the Supreme Court on due process grounds, Home Ins. Co. v. Dick, 281 U.S. 397 (1930), and, perhaps, on the basis of the full faith and credit clause. See Hughes v. Fetter, 341 U.S. 609 (1951). Except in the case of "transient jurisdiction," EmRENZwEIG, TREATISE 103-10; EHREN2WEIG, P.I.L. 107-10, application of the forum law would presumably be certiorariproof. Cf. International Shoe Co. v. Washington, 326 U.S. 310 (1945).

222 Wilcox v. Wilcox, 26 Wis. $2 d$ 617, 630-31, 133 N.W.2d 408, 415 (1965).

223 UnIform Commercial Code $\$ 1-105$, Comment 3 . As to the merits of this claim compare LEFLAR 228, with Ehrenzweig, Book Review, 16 AM. J. Courp. L. 615, 619 (1968). See also Panel Discussion on the Uniform Commercial Code, 12 Bus. LAw. 49, 68-75 (1956).

224 See Rosenberg, supra note 205, at 459-60; Rosenberg, Comments on Reich v. Purcell, 15 U.C.L.A.L. REv. 641, 645-47 (1968).

225 See text accompanying notes $212-15$ sipra. 
manner in which they presently exercise discretion suggests that they are influenced by the quality of conflicting substantive rules from which they are asked to select. ${ }^{226}$ It can hardly be said that judges are not equipped to make evaluations of this kind. The determination of what is fair poses less of a problem than application of some of the thornier new methodologies. Most of our tort law is judge-made and, except for occasional aberrations, ${ }^{227}$ judges on the whole have been at least as astute in creating tort rules as legislatures. The manner in which they resorted to praetorian powers ${ }^{228}$ to develop a law of products liability is a cogent example. ${ }^{229}$ That they will use these powers in an irrational fashion is unlikely so long as they are compelled to articulate reasons for preferring one rule over another and so long as court decisions can be overturned by constitutional review and legislative action. Moreover, most of the cases will be "easy" ones. There are hardly two points of view about guest statutes, limitations on wrongful death recovery, and intrafamily immunity. ${ }^{230}$ Other situations might pose more troublesome problems, ${ }^{231}$ but having to cope with such problems would not cause a misallocation of judicial resources. Reasoned opinions about the merits of a particular rule are of great practical value. Such opinions might induce legislatures to amend noxious domestic laws. ${ }^{232}$ At the very least, injustice in particular cases could be avoided.

226 See text accompanying notes 163-64, 181 supra.

227 See, e.g., Baker v. Bolton, 170 Eng. Rep. 1033 (N.P. 1808). The fact that this rule was modified by statute, Fatal Accidents Act of 1846,9 \& 10 Vict. c. 93 (Lord Campbell's Act), in turn had unfortunate consequences. The assumed need for statutes "creating" wrongful death recovery led other judges astray. See The Harrisburg, 119 U.S. 199 (1886).

228 This phenomenon is not unique to common law countries. See R. DAvid \& H. De VRIEs, The French Legal System 82, 95-96 (1958); A. von Merren, The CIVI LAW SYSTEM 337-462 (1957); R. Schlesinger, COMPARATIVE LAW 49-50, $360-65,372-82$ ( $2 \mathrm{~d}$ ed. 1959). The framers of the Rome Treaty were content to leave it up to the Court of Justice of the European Communities to fashion rules governing the liability of the European Economic Community for damage caused by its institutions or employees "in accordance with the general principles common to the laws of the Member States." Treaty Establishing The European Economic Community art. 215(2), effective Jan. 1, 1958, 298 U.N.T.S. 3. See generally Peck, The Role of the Courts and Legislatures in the Reform of Tort Law, 48 MnNN. L. REv. 265 (1963).

${ }_{229}$ See Jaeger, Product Liability: The Constructive Warranty, 39 NoTrE DaMe LAw. 501 (1964); Prosser, The Assanlt upon the Citadel (Strict Liability to the Consumer), 69 YALE L.J. 1099 (1960); Traynor, The Ways and Meanings of Defective Products and Strict Liability, 32 TenN. L. Rev. 363 (1965).

230 See note 151 supra.

This case is a comparatively easy one, and in cases like it the result will hereafter be reasonably easy for lawyers and trial judges to calculate. Admittedly there will be harder cases, more difficult to decide, cases that will not yield sure answers in terms of proper choice-influencing considerations as readily as this case does. That will not be a new phenomenon in conflict of laws. ... Most of the choice-of-law rules and results that have been reached in the past were supported by good sense and sound practical analysis ...

Clark v. Clark, 107 N.H. 351, 357, 222 A.2d 205, 210 (1966) (Kenison, C.J.). 232 See EHRENZWEIG, P.I.L. 102-03; Freund, Chief Justice Stone and the Confict of Lazes, 59 HARv. L. REv. 1210, 1216 (1946). 
Perhaps more important than the power and wisdom of the oracles of the law is their willingness to admit motives. The courage and honesty of the New Hampshire and Wisconsin judges and their avoidance of "gimmicks" and "cover-up" devices 233 must be admired. Their unabashed avowal of purposes places them beyond the reproach of intellectual dishonesty which recourse to subterfuge inevitably merits. ${ }^{234}$ Their opinions leave little doubt in the minds of the lawyers in these jurisdictions about the disposition of future cases. These opinions refute the contention that the teleological approach is a form of unprincipled cadi justice.

It has been said that "asking the judge simply to express a preference between . . . two rules on the score of 'justice and convenience' is to abolish our centuries-old subject." ${ }^{235}$ Indeed, if other jurisdictions were to follow the lead of New Hampshire and Wisconsin and adopt the better law rule, a uniform substantive law of interstate torts would emerge. Such a development, which is not entirely unprecedented, ${ }^{236}$ would spell the end of tort choice of law between the states of the Union. But the development of a rational body of rules bearing the imprimatur of judicial certification of superiority may be a more pleasing prospect than the demise of state law through federal preemption. ${ }^{237}$

As far as the subject of conflicts of law is concerned, it will weather the shock of uniformity in any given area of the law. Too much diversity remains. If private law conflicts should become uninteresting, the clash of regulatory laws, such as antitrust and securities legislation, offers a tempting field for exploration. If interstate conflicts are no longer sufficiently attractive, private international law presents the challenge. Lawyers will continue to find conflicts law "one of the most baffling subjects of legal science," ${ }^{238}$ because it attempts to reconcile the irreconcilable. The real danger for the pundits is that their stuporific shadowboxing will drive away their audience. ${ }^{239}$

233 LEFLAR 257-59.

234 Griswold, cited in Baade, supra note 172, at 161.

235 CAVERS 86.

236 For a discussion of the handling of the mobile torts of yesteryear by American admiralty courts see EERENZWEIG, P.I.L. 204-07, 222-23, 227-28.

237 For the latter possibility, see Tooker v. Lopez, 24 N.Y.2d 569, 591-92, 249 N.E.2d 394, 408, 301 N.Y.S.2d 519, 538-39 (1969) (Burke, J., concurring); Rosenberg, in Comments on Reich v. Purcell, 15 U.C.L.A.L. REv. 641, $645-46$ (1968).

238 B. Cardozo, The Paradoxes of Legal Science 67 (1928).

239

Wherever one's sympathies, gallons of ink spill across the law review pages as the conflicts revolution engages a counter-revolution in a rhubarb as esoteric and perplexing as anything American law has ever known.

Wright, The Federal Courts and the Nature and Quality of State Law, 13 WAyNe L. REv. 317, 334 (1967). 